\title{
WPLYW POLITYKI CHIŃSKIEJ REPUBLIKI LUDOWEJ NA REFORMY POLSKIEGO PAŹDZIERNIKA 1956
}

Pisząc o wydarzeniach polskiego Października 1956 r., autorzy zazwyczaj koncentrują się na procesach dokonujących się w Polsce, podkreślając znaczenie oporu społeczeństwa wobec władzy komunistycznej i walk frakcyjnych toczonych w Polskiej Zjednoczonej Partii Robotniczej (PZPR). Tymczasem ogromny wpływ na polskie przemiany miały wydarzenia rozgrywające się w całym bloku państw socjalistycznych, a także postawa wobec nich państw zachodnich. Artykuł ten jest poświęcony uwarunkowaniom zewnętrznym, które umożliwiły dokonanie rewolucyjnych - jak na owe czasy - przeobrażeń systemu PRL. Szczególną rolę odegrały tu procesy zachodzące w Chińskiej Republice Ludowej (ChRL) oraz jej próby uniezależnienia się od Moskwy i wzmocnienia swej pozycji w obozie państw socjalistycznych.

\section{Nowy układ sił w bloku pańsłw socjalistycznych i jego wpływ na sytuację w PZPR}

Po śmierci Józefa Stalina 5 marca 1953 r. w Związku Radzieckim zakończyły się rządy oparte na kulcie jednostki i wszechwładzy aparatu represji. Zaraz po usunięciu szefa NKWD Ławrientija Berii, który początkowo wydawał się głównym kandydatem na przywódcę ZSRR, krajem rządził faktycznie triumwirat: Georgij Malenkow - nowy premier, Wiaczesław Mołotow - minister spraw zagranicznych i Nikita Chruszczow. W związku z usunięciem Berii do przywódców państw socjalistycznych zaczęły docierać głosy na razie nieoficjalnej krytyki stalinowskiej tajnej policji ze strony władz ZSRR. W polityce zagranicznej Moskwa zaczęła od- 
chodzić od linii konfrontacji z Zachodem. Zmniejszyła się też jej kontrola nad innymi krajami obozu socjalistycznego, dzięki czemu mogły one podjąć nieco bardziej samodzielną politykę, zarówno wewnętrzną, jak i zagraniczną. Możliwe stały się między innymi wizyty przywódców państw socjalistycznych w innych krajach obozu. W zaistniałej sytuacji doszło do wzmożonych kontaktów między przywódcami Polski i ChRL. W 1954 r. ówczesny I sekretarz KC PZPR Bolesław Bierut odwiedził Chiny. W Polsce natomiast gościł premier ChRL Zhou Enlai.

Tymczasem faktycznym przywódcą ZSRR stał się Chruszczow. We wrześniu 1953 r. objął on nowo ustanowiony urząd I Sekretarza Komitetu Centralnego Komunistycznej Partii Związku Radzieckiego (KC KPZR). Jego pozycja jednak nie była nigdy tak silna jak pozycja Stalina, co sprzyjało słabnięciu kontroli Moskwy nad pozostałymi państwami bloku. Równocześnie rosła pozycja Chin, które zaczęły dążyć do uwolnienia się spod dyktatu Kremla i do oparcia stosunków z ZSRR na równoprawnych zasadach. Inne „bratnie partie” zaczęły oficjalnie podkreślać znaczenie Komunistycznej Partii Chin (KPCh). Przywódcy Korei Północnej pierwsi rozpropagowali slogan: „Obóz pokoju ze Związkiem Radzieckim i Chińską Republiką Ludową na czele", a w następnych latach stał się on powszechnie używany przez przywódców innych krajów bloku socjalistycznego. Do zmian sytuacji wewnątrz bloku przyczyniło się również zawarcie w 1953 r. rozejmu w Korei, co w praktyce kończyło tę wojnę i ostrą fazę konfrontacji zbrojnej z Waszyngtonem oraz z jego sojusznikami. W oficjalnej sowieckiej propagandzie hasło ,walki z imperializmem” zaczęło ustępować idei „pokojowego współistnienia”. W Polsce, wśród działaczy PZPR, narastała krytyka stalinizmu, a z czasem zaczęto poszukiwać alternatywy dla stalinowskiej drogi budowy socjalizmu z uwzględnieniem tak zwanej narodowej specyfiki.

Ponieważ w ZSRR trwały walki o schedę po Stalinie, w Chinach mogły się ujawnić skrywane dotychczas tendencje nacjonalistyczne przewodniczącego KPCh Mao Zedonga i części partyjnych przywódców. Zasadniczym celem przyjęcia ideologii komunistycznej nie była już dla nich realizacja narzuconej przez Moskwę wizji komunizmu. Traktowali oni ideologię komunistyczną raczej jako środek wiodący do celu, jakim była odbudowa potęgi $\mathrm{Chin}^{2}$. Zachowanie Stalina, który starał się hamować postępy Chińskiej Armii Ludowo-Wyzwoleńczej (ChALW) podczas wojny domowej 1946-1949, mogło dobitnie świadczyć, że zdawał on sobie sprawę z tych tendencji w kierownictwie chińskim ${ }^{3}$. W Chinach przejęcie władzy przez

1 Za Wojciech Roszkowski, Historia Polski 1914-1996, Wydawnictwo Naukowe PWN, Warszawa 1997, s. 225.

${ }^{2}$ Waldemar J. Dziak, Jerzy Bayer, Mao: Zwycięstwa, nadzieje, klęski, Instytut Studiów Politycznych PAN, Collegium Civitas, Wydawnictwo TRIO, Warszawa 2007, s. 17-18.

3 Zob. np. Catherine i Jacques Legrand (red.), Mao Zedong, Bellona, Warszawa 2000, s. 76. 
partię komunistyczną było następstwem zwycięstwa armii rewolucyjnej, składającej się głównie z chłopów. Zwycięstwo to było efektem masowego poparcia dla KPCh i dokonało się bez większego zaangażowania czy entuzjazmu Moskwy.

Stalinowi nie podobały się „heretyckie” podejście Mao do marksizmu, a przede wszystkim nacjonalizm. Obawiał się ambicji Mao do przewodzenia blokowi komunistycznemu. Nazywał chińskiego przywódcę „drugim Tito” i „margarynowym marksistą" ". Związek Sowiecki był pierwszym krajem, który uznał Chiny Ludowe już 2 października 1949 r., ale był też ostatnim krajem, który uznał przegraną narodowców - Guomindangu (GMD) pod przywództwem Czang Kaj-szeka (Jiang Jieshi) w wojnie domowej. W czasie gdy ChALW odnosiła wielkie sukcesy militarne, Stalin nakłaniał Mao do zaprzestania walki i utworzenia z Czangiem rządu koalicyjnego. Początkowo demonstrował nawet poparcie dla chińskich nacjonalistów. W 1945 r. został zawarty traktat o przyjaźni i sojuszu między ZSRR a Chinami guomindangowskimi, w którym znalazło się stwierdzenie, że Związek Radziecki zobowiązuje się do niesienia pomocy „materialnej i moralnej”, kierowanej do GMD „sprawującej jedyną legalną władzę"5.

Po ustanowieniu ChRL postawa Stalina wobec niej również wywoływała niezadowolenie w Pekinie. Jego przyczynami były osobiste doświadczenia chińskich komunistów, związane z ingerencjami Moskwy w wewnętrzne sprawy KPCh, oraz nierównoprawne relacje i nieprzestrzeganie suwerenności chińskiego partnera, co w Chinach traktowano jako „wielkomocarstwowy szowinizm” (choć o tym głośno się nie mówiło). Pamiętano też dewastację i rabunek Mandżurii przez Armię Czerwoną w latach 1945-1946. Boleśnie odbierano narzucanie przez Moskwę nierównoprawnych zasad w stosunkach gospodarczych, wymuszone stacjonowanie radzieckich wojsk w Lüshun (Port Artur), niedotrzymanie przez Stalina zobowiązań związanych z kosztami uczestnictwa „chińskich ochotników” w wojnie koreańskiej, wreszcie utworzenie niepodległej Mongolii, którą elity chińskie uważały tradycyjnie za część Chin 6 .

Po 1953 r. sytuacja w ZSRR stworzyła Chinom okazję do zmiany tych relacji. Aby złagodzić kryzys, nowe kierownictwo radzieckie musiało dokonać reform, które nie budziły entuzjazmu sporej grupy konserwatystów w KPZR. Ponieważ Chruszczow potrzebował poparcia Pekinu, przywódcy chińscy mogli wreszcie przystąpić do realizacji planów wyswobodzenia się spod kurateli Moskwy, a w perspektywie nawet objęcia przez ChRL przywództwa w bloku komunistycznym. Dużą

${ }^{4}$ Ross Terrill, Mao - biografia, Iskry, Warszawa 2001, s. 232.

5 C. i J. Legrand (red.), Mao Zedong, s. 77.

${ }^{6}$ Jan Rowiński, ChRL a wydarzenia październikowe 1956 r. w Polsce. Czy Chińczycy uchronili nasz kraj przed radziecka interwencją?, [w:] Bogdan Góralczyk (red.), Polska-Chiny: wczoraj, dziś, jutro (w 60-lecie stosunków), Wydawnictwo Adam Marszałek, Toruń 2009, s. 284-286. 
rolę w chińskiej polityce zagranicznej odegrały też osobiste ambicje Mao, który uważał się za następcę Stalina jako przywódcy bloku komunistycznego ${ }^{7}$. Wyrazem nowego kursu w polityce Pekinu była nieobecność przewodniczącego KPCh na pogrzebie Stalina, na który zjechali niemal wszyscy przywódcy komunistyczni.

Przejawem rosnącej pozycji Chin było kreowanie się KPCh na nieformalnego lidera azjatyckich partii komunistycznych. W listopadzie $1953 \mathrm{r}$. ChRL podpisała traktat o współpracy gospodarczej i kulturalnej z Koreą Północną. Zobowiązała się ona udzielić pomocy gospodarczej w odbudowie Korei - dotychczas wszelka pomoc gospodarcza była udzielana wyłącznie przez ZSRR. „Trybuna Ludu” opublikowała z tej okazji fragment przemówienia premiera ChRL Zhou Enlaia, wygłoszonego z okazji podpisania traktatu. Zhou stwierdził między innymi: Układ nasz jest wyrazem potężnej jedności narodów Azji. [...] Zbudzone i budzace się narody Azji nigdy nie ścierpia zniewag ani agresji. Ci, którzy nie zechca się z tym liczyć, z cała pewnościa będa i w przyszłości brać cięgi ${ }^{8}$.

Wzrastająca pozycja Chin w bloku państw socjalistycznych wpływała także na propagandę PRL. Począwszy od 1954 r., w polskiej prasie coraz częściej pojawiały się stwierdzenia, że Chiny Ludowe są „,wielkim mocarstwem” (pisano o tym w kontekście prób przeforsowania przyjęcia tego kraju do ONZ). W jednym z artykułów „Trybuny Ludu” stwierdzono: Dawno skończyła się wojna narodowo-wyzwoleńcza, kiedy woczach zdumionego świata Ludowa Armia Chińska w legendarnym marszu, w ciagu 2,5 lat wyzwoliła swój kraj równy obszarem całej Europie ${ }^{9}$.

W 1954 r. w drodze powrotnej z konferencji genewskiej (26 kwietnia-20 lipca 1954 r.) Zhou Enlai odwiedził Warszawę. Jego wizyta (26-28 lipca) była wyjątkowo mocno nagłośniona w prasie. Nie wiązała się ona z żadnym zjazdem czy rocznicą, premier Zhou przyjechał na zaproszenie władz polskich. Relacje z wizyty zajmowały niemal całe pierwsze strony i sporo miejsca w wydaniach „Trybuny Ludu”. Wizyta zapoczątkowała okres ożywionych kontaktów dyplomatycznych między oboma krajami.

Niemałym szokiem dla ówczesnych elit PRL musiał być wynik rokowań radziecko-chińskich na wysokim szczeblu, zakończonych w październiku $1954 \mathrm{r}$. Przede wszystkim postanowiono wycofać wojska radzieckie z Port Artur. Wśród innych postanowień ZSRR zobowiązał się przekazać Chinom swe udziały w chińsko-radzieckich spółkach działających na terenie ChRL, a równowartość radziec-

${ }^{7}$ J. Rowiński, Wahadło: czyli stosunki polityczne PRL-ChRL, [w:] B. Góralczyk (red.), Polska-Chiny..., s. 17.

${ }^{8}$ Wyraz potężnej jedności narodów Azji, „Trybuna Ludu”, 26 listopada 1953, s. 2 [we wszystkich cytatach zachowana jest pisownia oryginalna - Redakcja].

9 Majowy uśmiech Chin, ,,Trybuna Ludu”, 5 maja 1954, s. 3. 
kich udziałów miała zostać spłacona chińskim eksportem. Również port cywilny w Dalianie, współużytkowany przez Rosjan, został zwrócony Chińczykom.

W kwietniu 1955 r. pojawiły się w Polsce informacje o rozbiciu „kliki Gao i Rao"10 (od nazwisk dwóch działaczy KPCh - Gao Ganga i Rao Shushi), przy czym głównym celem ataków był Gao Gang - przywódca partii w regionie Chin Północno-Wschodnich i szef Centralnej Komisji Planowania. Faktycznie kierował on chińską gospodarką, odpowiadając za wprowadzenie w ChRL radzieckiego modelu gospodarczego. Ponadto Gao uchodził za kluczowego „człowieka Moskwy” w chińskim kierownictwie. Dlatego właśnie atak na jego osobę mógł być odczytywany jako ostrzeżenie przed nadmiernym mieszaniem się ZSRR w wewnętrzne sprawy ChRL ${ }^{11}$. Trzeba dodać, że usunięcie Gao stanowiło element większej czystki związanej z przekazaniem Chinom przez Chruszczowa - w geście dobrej woli - listy nazwisk radzieckich agentów działających na terenie ChRL. Dla osób zorientowanych jego potępienie mogło być oznaką pojawienia się konfliktu między dwoma wielkimi mocarstwami w bloku komunistycznym, a nawet eliminowania nazbyt proradzieckich działaczy. W Polsce wiedzę taką miała oczywiście bardzo wąska grupa czołowych działaczy PZPR.

Rosnąca pozycja ChRL wobec ZSRR i stopniowe uniezależnianie się Pekinu od Moskwy musiały prowadzić do konfliktów między oboma mocarstwami. Przywódcom Chin Ludowych udało się początkowo wykorzystywać nowy układ polityczny w ZSRR. Ponieważ pozycja nowego szefa KPZR była niepewna, to on właśnie musiał zabiegać o chińskie poparcie dla konsolidacji swej władzy. Jedną z metod zjednywania sobie Chin było wycofanie się z upokarzających traktatów zawartych z ChRL za rządów Stalina. Mao Zedong żądał jednak więcej - od lat domagał się odzyskania Mongolii będącej krajem satelickim ZSRR. Do sprawy tej powrócono również w rozmowach z Chruszczowem, a gdy ten odmówił, w prasie chińskiej pojawiły się artykuły kwestionujące przebieg granicy chińsko-radzieckiej. Chińczycy zaczęli proponować ponadto pomoc gospodarczą nie tylko Korei Północnej, ale i Wietnamowi Północnemu, a wreszcie krajom Europy Wschodniej, co stanowiło pogwałcenie zasady, zgodnie z którą pomocy takiej mógł udzielać im tylko Związek Radziecki.

${ }^{10}$ Komunikat KC Komunistycznej Partii Chin o ogólnokrajowej konferencji KPCh, „Trybuna Ludu", 6 kwietnia 1955, s. 2.

11 W.J. Dziak, J. Bayer, Mao..., s. 35. 


\section{"Chińska odmiennośćc jako ideologiczne uzasadnienie reform w Polsce}

Od 1954 r. w PZPR zaczęła narastać krytyka metod stalinowskich. Dochodziło do pierwszych zmian w funkcjonowaniu aparatu władzy. Już w 1953 r. znacznie spadła liczba aresztowań i wyroków w sprawach politycznych, co było efektem walki z „beriowszczyzną"12. W następnym roku coraz częściej pojawiały się głosy krytyki poczynań kierownictwa partii, a przede wszystkim wszechobecnej służby bezpieczeństwa. Problemy ekonomiczne doprowadziły do wzrostu niezadowolenia społecznego. W tej sytuacji w marcu 1954 r. dokonano korekty planu sześcioletniego i przesunięto część środków inwestycyjnych przeznaczonych na rozwój przemysłu ciężkiego i sektora wojskowego do rolnictwa, przemysłu spożywczego oraz mieszkaniowego ${ }^{13}$. Wiązało się to z prowadzoną przez ZSRR polityką odprężenia w stosunkach z USA i zmniejszeniem nakładów na obronność w bloku komunistycznym. We wrześniu 1954 r. doszło do strajku w poznańskich Zakładach Metalowych im. Józefa Stalina (Cegielskiego). Władze, które dotychczas brutalnie thumiły wszelkie przejawy protestu, tym razem ostatecznie - choć nie bez represji - ustąpiły przed żądaniami strajkujących ${ }^{14}$.

Od września 1954 r. zaczęły się pojawiać w programach Radia Wolna Europa audycje Józefa Światły, byłego wicedyrektora departamentu w Ministerstwie Bezpieczeństwa Publicznego, który po ucieczce na Zachód ujawnił metody działania służb specjalnych PRL. Informacje ujawnione przez Światłę stały się dzięki temu znane w Polsce, co wstrząsnęło nie tylko opinią publiczną, ale i członkami PZPR. Szeregowi członkowie, a nawet działacze dowiedzieli się z nich, jakimi metodami posługują się służby specjalne PRL, kierownictwo zaś zdało sobie sprawę ze skali inwigilacji, jakiej podlegali nawet działacze wyższego szczebla hierarchii partyjnej.

Ucieczka Światły była prawdopodobnie wynikiem jego obawy przed czystkami w aparacie bezpieczeństwa inspirowanymi przez Chruszczowa ${ }^{15}$. Bez względu jednak na jej motywy całe zdarzenie świadczy o tym, że już wtedy poczynania działaczy PZPR były reakcją na sygnały dochodzące z Moskwy. Na fali przemian zwolniono z więzienia Władysława Gomułkę (aresztowanego 2 sierpnia $1951 \mathrm{r}$. za tak zwane prawicowo-nacjonalistyczne odchylenie). W listopadzie na zebraniu aktywu partyjnego Bolesław Bierut złożył samokrytykę w związku z łamaniem

12 Andrzej Leon Sowa, Historia polityczna Polski 1944-1991, Wydawnictwo Literackie, Kraków 2011, s. 198-199.

${ }^{13}$ Edmund Makowski, Poznański czerwiec 1956. Pierwszy bunt społeczeństwa, Wydawnictwo Poznańskie, Poznań 2001, s. 16.

${ }^{14}$ W. Roszkowski, Historia Polski..., s. 225.

15 Andrzej Werblan, Październik 1956 - legendy a rzeczywistość, [w:] J. Rowiński (red.), Polski październik 1956 w polityce światowej, Polski Instytut Spraw Międzynarodowych, Warszawa 2006, s. 16-17. 
zasady praworządności $\mathrm{w}$ partii. $\mathrm{W}$ prasie zaczęto zamieszczać pozytywne opinie o kulturze i muzyce pochodzącej z Zachodu ${ }^{16}$. W kinach pojawily się po raz pierwszy zachodnie filmy ${ }^{17}$. Ferment, jaki objął szeregi partii, stał się zauważalny już w kwietniu 1954 r. Jak pisała w dziennikach Maria Dąbrowska: „Teraz partyjni wygadują niestworzone rzeczy na rezultaty stworzonego przez nich ustroju"18.

Niezwykle istotna z punktu widzenia działaczy PZPR dążących do reformy systemu była ówczesna polityka wewnętrzna Pekinu. Chociaż sposób przedstawiania Chin Ludowych przez propagandę PRL był jeszcze w 1953 r. typowy dla propagandy stalinowskiej, to już wtedy osoby zainteresowane Chinami mogły odnaleźć informacje o ich odmienności. Okazją do tego stało się opublikowanie w Polsce przetłumaczonych z rosyjskiego Dzieł wybranych Mao Zedonga ${ }^{19}$. Choć w dużej mierze zostały one przeredagowane przez radzieckich ideologów, wskazują na pewną specyfikę chińskiej drogi do socjalizmu i wizji Mao.

Jak wynika z lektury Dziet, przejęcie z marksizmu teorii walki klas jako motoru rewolucji nie oznaczało opowiedzenia się za poglądem, zgodnie z którym decydująca dla chińskiej rewolucji będzie walka między klasą robotniczą a kapitalistami, czyli proletariatu miejskiego z burżuazją. Przeciwnie, Mao - podważając tę podstawową zasadę marksizmu - przekonywał, że źródeł rewolucji w Chinach trzeba szukać w walce klasowej na wsi. Ogólnie rzecz biorąc, im niżej w hierarchii ekonomicznej stoi dana grupa społeczna, tym bardziej skłonna jest do popierania rewolucji, najliczniejszą zaś, a zarazem najbiedniejszą grupę społeczną w Chinach stanowili chłopi. Oczywiście taka koncepcja rewolucji wymagała uzasadnienia na gruncie marksistowskim.

Podstawowym problemem ideologicznym wiążącym się ze specyfiką chińskiej rewolucji była nieprzystawalność historii Chin do marksistowskiej wizji rozwoju społecznego. O ile marksiści radzieccy mogli uznać - przy odrobinie dobrej woli - że w kraju tym panował feudalizm, to nie dało się udowodnić, że po nim nastąpiło przejście do kapitalizmu. W Dziełach znajduje się więc ideologiczne uzasadnienie twierdzenia, że mimo tej luki można w Chinach dokonać przejścia do socjalizmu. Czytając Dzieła, dowiadujemy się, że rewolucja burżuazyjno-demokratyczna w Państwie Środka była procesem powolnym i trwała od roku 1840. Rewolucja 1911 r. zakończyła pierwszy jej etap, drugi zaś etap - Ruch 4 Maja 1919 r. Był to okres zasadniczych zmian w sytuacji na świecie po powstaniu pierwszego państwa komunistycznego.

${ }^{16}$ Maria Dąbrowska, Dzienniki powojenne 1945-1965, t. 2, Czytelnik, Warszawa 1996, s. 427.

17 E. Makowski, Poznański czerwiec..., s. 17.

18 M. Dąbrowska, Dzienniki powojenne..., t. 2, s. 429.

19 Mao Tse-tung, Dzieła wybrane, t. 1-3, Książka i Wiedza, Warszawa 1953-1955, t. 4, Warszawa 1958. 
Od czasu Ruchu 4 Maja na czele rewolucji burżuazyjno-demokratycznej w Chinach stanął proletariat, zmieniły się także jej cele. O ile wcześniej dążono do powstania „demokracji burżuazyjnej”, o tyle po 1919 r. nowym celem rewolucji burżuazyjno-demokratycznej stało się zbudowanie „,nowej demokracji”. Ta specyficzna forma ustrojowa miała stanowić fazę przejściową między fazą kolonializmu i feudalizmu a komunizmem, typową dla wszystkich krajów kolonialnych lub półkolonialnych. W okresie ,nowej demokracji” władzę miał sprawować sojusz rewolucyjnych klas obejmujący także drobną burżuazję. Ta bowiem skłonna była poprzeć chińską rewolucję ${ }^{20}$.

W systemie ,nowej demokracji” państwo powinno być rządzone przez zgromadzenia przedstawicieli ludowych różnego szczebla, wybierane w równych wyborach i wybierające przedstawicieli organów władzy na danym szczeblu administracji. Realizację woli ludu zapewnić zaś miało wprowadzenie centralizmu demokratycznego. Przy podziale władzy miał obowiązywać system ,trzech trzecich”. Zarówno w nowodemokratycznych ciałach przedstawicielskich, jak i w administracji członkowie partii komunistycznej powinni stanowić jedną trzecią. Pozostałe dwie trzecie powinny przypaść innym partiom i niezależnym kandydatom, opowiadającym się za walką z imperializmem.

Jak widać, nie miał być to system, w którym wybory są w pełni wolne. Raczej miał stanowić formę pośrednią między systemem jednopartyjnym a demokracją wielopartyjną ${ }^{21}$. W fazie „nowej demokracji” państwo powinno chronić burżuazję poprzez unikanie nadmiernego opodatkowania przedsiębiorstw prywatnych i zbytniego rozszerzania przywilejów pracowniczych, gdyż mogłoby to doprowadzić do spadku produkcji. Dawni posiadacze ziemscy mieli być traktowani na równi z innymi chłopami, zwłaszcza przy podziale ziemi ${ }^{22}$. Te zabiegi powinny stworzyć warunki do powołania wielkiej, zjednoczonej koalicji w celu walki z imperialistami i przeprowadzenia rewolucji burżuazyjno-demokratycznej. Idea „nowej demokracji” opierała się więc na założeniu, że zarówno rewolucję komunistyczną, jak i burżuazyjno-demokratyczną można przeprowadzić pod kierownictwem proletariatu i partii komunistycznej, wykorzystując napięcia występujące na chińskiej wsi.

Z lektury Dziet wybranych wynika, że w Chinach inaczej wyobrażano sobie budowę socjalizmu po zwycięstwie rewolucji proletariackiej, co stało się później elementem sporu między KPZR i KPCh. Jak czytamy w Dziełach, zwycięstwo komunizmu nie będzie zakończeniem walki różnych idei i koncepcji politycznych. Założenie powyższe wiąże się z maoistowską zasadą jedności przeciwieństw, we-

${ }^{20}$ Idem, O klasach społecznych w Chinach, [w:] Dzieła wybrane, t. 2, s. 21-22.

${ }^{21}$ Idem, O calkowite zespolenie, [w:] Dzieła wybrane, t. 3, s. 321-322 oraz O naszej polityce, [w:] Dzieła wybrane, t. 3, s. 333.

${ }^{22}$ Idem, O naszej polityce, s. 333-334. 
dle której sprzeczności są podstawą rozwoju społecznego ${ }^{23}$. Według tej koncepcji istnieją sprzeczności wywołujące antagonizmy, na przykład między pracą a kapitałem. Są też sprzeczności, które nie wywołują antagonizmów, przynajmniej jeśli się do tego nie dopuści. Przykładem jest sprzeczność między robotnikami a chłopami w społeczeństwie socjalistycznym. Sprzeczności niewywołujące antagonizmów znikają stopniowo w trakcie procesu rozwoju społecznego. Sprzeczności wewnątrz partii komunistycznej są w większości sprzecznościami niewywołującymi antagonizmów, chyba że pozostawi się je nierozwiązane. Pomóc w ich rozwiązaniu mają zaś krytyka błędnych poglądów i samokrytyka ich głosicieli. Stosowanie tych metod umożliwia błądzącym powrót na słuszną drogę.

Według Mao sprzeczności są stałym elementem życia społecznego. Rozwiązanie jednej sprzeczności powoduje zakończenie pewnego procesu i powstanie nowej sprzeczności, a więc początek nowego procesu. Społeczeństwo znajduje się w nieustannym rozwoju polegającym na pojawianiu się coraz to nowych sprzeczności. Brak sprzeczności oznaczałby upadek społeczeństwa. Zwycięstwo rewolucji i stworzenie dyktatury proletariatu miało prowadzić do likwidacji państwa w ogóle, a zwycięstwo partii komunistycznej - do likwidacji partii jako instytucji społecznej. W Dziełach znajdujemy krytykę poglądu mówiącego, że wyłącznie baza ekonomiczna oddziałuje na nadbudowę, materia na pierwiastek duchowy, a byt społeczny na świadomość społeczną. Czytamy, że oddziaływanie to jest oddziaływaniem wzajemnym, a w określonych warunkach również w przypadku tych sprzeczności dochodzi do zastąpienia strony głównej przez stronę drugorzędną ${ }^{24}$. Twierdzenie to stało się w przyszłości ideologicznym uzasadnieniem „,rewolucji kulturalnej”.

W świetle tekstów zawartych w Dziełach wybranych powstanie marksizmu nie było dla Mao Zedonga końcem historii wiedzy. Ponieważ uważał, że rzeczywistość jest zmienna, traktował proces tworzenia teorii jako zjawisko ciągłe. Marksizm natomiast miał stanowić jedynie podstawę dalszych poszukiwań. Dzięki publikacji Dzieł wybranych osoby zainteresowane Chinami mogły się przekonać, że chińskie i stalinowskie metody budowy socjalizmu różnią się w sposób istotny. Dzieła dawały również ideologiczne - i, co najważniejsze, akceptowane przez Moskwę - podstawy istnienia „chińskiej odmienności”. Pisanie więc o niej w prasie partyjnej w latach późniejszych mieściło się w narzuconej przez Moskwę ideologii. Nic więc dziwnego, że partyjna inteligencja polska, coraz bardziej sceptyczna wobec dogmatycznego marksizmu stalinowskiego, potraktowała koncepcje chińskie jako ożywczy powiew w ideologii marksistowskiej.

${ }^{23}$ Idem, W sprawie sprzeczności, [w:] Dzieła wybrane, t. 3, s. 321-322 oraz O naszej polityce, s. 341 .

${ }^{24}$ Idem, W sprawie sprzeczności, s. 364-365. 
Od momentu powstania ChRL podkreślano w Polsce odmienność - do pewnego stopnia - tego państwa od pozostałych krajów komunistycznych. Zaznaczano jednak, że odmienności te wynikają ze specyficznie chińskich warunków i mają charakter przejściowy. Przede wszystkim mówiło się o sojuszu różnych klas, w tym kapitału z robotnikami, w ramach systemu „nowej demokracji”. System ten miał odróżniać Chiny Ludowe od Związku Radzieckiego, gdzie panowała dyktatura proletariatu. Jednocześnie z zasady sojuszu tak zwanych klas rewolucyjnych wynikało istnienie wielu partii politycznych reprezentujących różne klasy ${ }^{25}$. Innym przejawem „chińskiej odmienności” było tolerowanie prywatnych przedsiębiorstw, sklepów, domów towarowych oraz dominacja w rolnictwie indywidualnych gospodarst ${ }^{26}$. Prywatne przedsiębiorstwa i gospodarstwa rolne miały być stopniowo przekształcane we własność państwową. Była to metoda zupełnie odmienna od brutalnej nacjonalizacji i kolektywizacji stosowanych w czasach stalinowskich.

Od 1954 r. w prasie PRL coraz więcej uwagi poświęcano „chińskiej odmienności”. Z doniesień prasowych wynikało też, że Związek Radziecki akceptował ją w okresie przejścia do socjalizmu. Przejawem tej postawy mogła być znaczna pomoc gospodarcza ZSRR przeznaczona na rozwój Chin. Sam Chruszczow w przemówieniu wygłoszonym z okazji piątej rocznicy powstania ChRL powiedział między innymi: Rząd ludowy i Komunistyczna Partia Chin troszczą się również o wykorzystanie olbrzymich możliwości, jakimi dysponuje gospodarka indywidualna. Podniesienie aktywności produkcyjnej indywidualnych gospodarstw rolnych, mobilizowanie ich do walki o uzyskanie wysokich plonów odgrywaja bardzo ważna role w zwiększaniu produkcji rolnej kraju².

W „Nowych Drogach” - miesięczniku ideologicznym i politycznym KC PZPR - pisano o roli burżuazji narodowej w chińskiej rewolucji i odbudowie kraju, dodając przy tym, że również w innych krajach Azji Wschodniej burżuazja narodowa stawała się sojusznikiem mas $\mathrm{w}$ walce $\mathrm{z}$ imperializmem ${ }^{28}$. Nie było więc chyba przypadkiem, że w tym czasie również w Polsce zaczęto mówić o wspieraniu

${ }^{25}$ W ChRL, obok KPCh, legalnie funkcjonuje osiem partii politycznych, tzw. chińskich partii demokratycznych. Są to: Rewolucyjny Komitet Chińskiego Guomindangu, Chińska Liga Demokratyczna, Chińskie Stowarzyszenie Demokratycznej Budowy Państwa, Chińskie Stowarzyszenie Promowania Demokracji, Chłopsko-Robotnicza Demokratyczna Partia Chin, Chińska Partia Dążenia do Sprawiedliwości, Stowarzyszenie Naukowe Trzeciego Września i Demokratyczna Liga Autonomii Tajwanu. Po czystkach związanych z „kampanią antyprawicową” w 1957 r. ich rola uległa marginalizacji.

${ }_{26}$ U stóp mauzoleum Sun Jat-sena, ,Trybuna Ludu”, 14 stycznia 1954, s. 6.

27 Wspólna walka ZSRR $i$ Chin o pokój, „Trybuna Ludu”, 3 października 1954, s. 3.

${ }_{28}$ Witold Rodziński, Zmiany w Azji, „Nowe Drogi”, marzec 1955, nr 3, s. 58-59. 
prywatnego rolnictwa ${ }^{29}$. Władze PRL mogły dostrzegać w chińskich realiach precedens do zmiany swej polityki. Odstąpienie od kolektywizacji związane z oporem polskich rolników zyskało ideologiczne uzasadnienie.

Wprawdzie w czasach stalinowskich komuniści w krajach satelickich ZSRR stosowali różne metody wprowadzania i utrwalania swej władzy, jednak bardzo szybko doszło w nich do stworzenia systemu opartego możliwie najbardziej na wzorach radzieckich. Inaczej stało się w Chinach. Moskwie nigdy nie udało się w pełni narzucić tam swej wersji socjalizmu. Gdy zaś doszło do zerwania z ZSRR, system polityczny ChRL ewoluował w zupełnie innym kierunku niż radziecki.

Można zatem powiedzieć, że od samego początku istnienia Chiny Ludowe mogły być wykorzystywane jako poparcie tezy, że w bloku państw komunistycznych możliwe jest współistnienie różnych metod budowy socjalizmu. Od 1954 r. fakt ten wykorzystywali przywódcy PRL, gdy próbowali ideologicznie uzasadnić prowadzoną przez siebie politykę. Ograniczeniu presji władz na kolektywizację w rolnictwie towarzyszyła więc kampania informacyjna na temat tolerowania prywatnej własności w Chinach i akceptacji tej polityki ze strony przywódców Związku Radzieckiego.

Informacje świadczące o stopniowym uniezależnianiu się ChRL od Moskwy, jak również promowanie Chin jako wielkiego mocarstwa, które obok Związku Radzieckiego stanowi „główne ogniwo całego obozu pokoju”, mogły oznaczać dla przywódców PZPR, że ZSRR nie jest już hegemonem narzucającym wolę innym krajom komunistycznym. Przy tym odmienność chińskiej drogi do socjalizmu i fakt akceptowania jej przez Moskwę wskazywały na możliwe istnienie w ruchu komunistycznym pluralizmu uwzględniającego narodową specyfikę różnych państw. W sytuacji, gdy w PZPR narastała krytyka stalinizmu, informacje o rosnącej pozycji Pekinu mogły zatem stanowić próbę inspirowania aktywu partyjnego, by ten poparł odchodzenie od stalinowskich metod rządzenia.

Jednak w 1955 r. doszło do zasadniczej zmiany w polityce ChRL. Mao Zedong żądał przyśpieszenia tempa socjalistycznych przemian, a przede wszystkim kolektywizacji rolnictwa oraz transformacji form własności przemysłu i handlu. Kampanię tę nazwano małym skokiem w odróżnieniu od wielkiego skoku z lat 1958-1960. W jej wyniku przeprowadzono całkowitą kolektywizację rolnictwa. W przemyśle i handlu doszło do przekształcenia prywatnych firm w przedsiębiorstwa państwowo-prywatne, które pozostawały pod całkowitą kontrolą państwa, chociaż dawni właściciele otrzymywali corocznie wysokie dywidendy od wniesionego przez nich kapitału, a często pełnili w nich funkcje kierownicze.

${ }_{29}$ Zob. np. Władysław Kruczek, Kojarzenie walki o rozwój produkcji indywidualnych gospodarstw chłopów pracujących i spółdzielczości produkcyjnej (w świetle praktyki woj. bydgoskiego), „Nowe Drogi”, maj 1954, nr 5, s. 47-61. 
W czasie, gdy w Chinach rozpoczynał się mały skok, z Moskwy docierały kolejne sygnały mogące świadczyć, że Chruszczow był skłonny akceptować odmienności w procesach budowy socjalizmu. Jak donosiła prasa, w deklaracji radziecko-jugosłowiańskiej podpisanej w Belgradzie podczas wizyty Chruszczowa na przełomie maja i czerwca 1955 r. stwierdzono, że dopuszczalne są różnice między sposobami rozwoju socjalizmu. Uznano też możliwość wyboru własnej drogi przez kraje wchodzące w skład bloku socjalistycznego ${ }^{30}$. W związku z tym spadło zainteresowanie polskiej prasy Chinami, a wzrosło zainteresowanie Jugosławią i jej odmienną drogą budowy socjalizmu.

\section{Inspiracje elit PRL politykq̨ Chin po XX zjeździe KPZR - kampania stu kwiatów i VIII zjazd KPCh}

XX zjazd KPZR stanowił punkt zwrotny w procesie odchodzenia od stalinizmu w Polsce. W zupełnie nowym położeniu znalazły się partie rządzące w krajach komunistycznych po wygłoszeniu przez Chruszczowa referatu $O$ kulcie jednostki i jego skutkach (24 i 25 lutego 1956 r. na zamkniętej sesji zjazdu), który miał mu ułatwić walkę z konserwatywnymi frakcjami w partii. Zasadniczym celem Chruszczowa było prawdopodobnie umocnienie i zracjonalizowanie systemu władzy. Potępiał on zbrodnie Stalina dokonane wobec członków partii tylko po to, by uwolnić aparat partyjny od strachu i zachęcić do awansowania jego pracowników. Za czasów Stalina bowiem wielu ludzi bało się zajmować najwyższe stanowiska ${ }^{31}$. Wbrew woli Chruszczowa referat wywołał jednak w krajach komunistycznych ferment mogący zagrozić sowieckiej hegemonii.

Referat przede wszystkim był ciosem dla przywódców partii krajów satelickich, opierających swoją władzę na autorytecie Stalina i ZSRR. Oto po raz pierwszy krytyka Stalina i informacje o nadużyciach w sprawowanej przez niego władzy pochodziły nie od „zachodnich rewizjonistów” czy „elementów wywrotowych”, ale wyszły z ust głównego przywódcy bloku. Dla reformatorów w partiach krajów satelickich referat zaś był sygnałem świadczącym, że nadszedł czas zmian. Jedni i drudzy mogli realizować własną politykę jedynie poprzez uzyskanie większej niezależności od ZSRR. W rezultacie blok komunistyczny stał się jeszcze mniej spójny $^{32}$. W samym ZSRR postępowała liberalizacja - w $1956 \mathrm{r}$. zwolniono z łagrów kilka milionów więźniów. Nie ukarano natomiast sprawców zbrodni stalinowskich, jeśli nie liczyć upomnień partyjnych.

\footnotetext{
${ }^{30}$ Paulina Codogni, Rok 1956, Prószyński i S-ka, Warszawa 2006, s. 145.

31 Roj A. Miedwiediew, Chruszczow. Biografia polityczna, Czytelnik, Warszawa 1990, s. 92.

32 W.J. Dziak, J. Bayer, Mao ..., s. 90-91.
} 
W Polsce referat Chruszczowa przyczynił się do radykalnego zaostrzenia walki frakcyjnej, tym bardziej że wkrótce po jego wygłoszeniu 12 marca podczas wizyty w Moskwie umarł Bolesław Bierut. Wyodrębniły się wówczas dwie główne frakcje w partii, biorące nazwy od miejsc spotkań ich liderów. „Natolińczycy”, którzy spotykali się w pałacu natolińskim pod Warszawą, składali się głównie z działaczy pochodzenia robotniczego i chłopskiego. Wstąpili oni do partii ze względów społecznych, wyrażając bunt przeciwko biedzie i dyskryminacji. Ich poglądy były silnie determinowane przez ich pochodzenie społeczne i brak wykształcenia. Byli to jednak ideowcy, niejednokrotnie przed rokiem 1945 więzieni za przekonania. Uważali, że za zbrodnie stalinowskie odpowiedzialni są ludzie, nie zaś system, a w Polsce odpowiedzialność ta spoczywa na rządzącym do początku 1956 r. triumwiracie: Bolesław Bierut, Jakub Berman i Hilary Minc. To ci trzej właśnie mieli odsunąć od władzy przedstawicieli klasy robotniczej i oprzeć się na działaczach wywodzących się z drobnomieszczaństwa, często pochodzenia żydowskiego. „Natolińczycy” nie uważali za konieczne dokonania radykalnej reformy systemu. Według nich, aby uleczyć system, wystarczyło tylko ukarać winnych zbrodni. Nie widzieli też konieczności zmiany stosunków z Moskwą, polegających faktycznie na całkowitej zależności Polski od ZSRR. Ze względu na konserwatywne poglądy cieszyli się oni uznaniem Kremla ${ }^{33}$.

„Puławianie” (kilku przywódców frakcji mieszkało przy ulicy Puławskiej w Warszawie) uważali, że za zbrodnie stalinowskie odpowiedzialny jest system. Karanie winnych nie przyniesie zasadniczych zmian, ponieważ to system stworzony w czasach stalinowskich był kryminogenny. Należy więc dokonać pewnej liberalizacji w państwie i demokratyzacji wewnątrz partii, aby w ten sposób zwiększyć kontrolę nad rządzącymi i uniknąć nadużyć. „Puławianie” opowiadali się też za większym otwarciem Polski na świat i oparciem stosunków z ZSRR na bardziej partnerskich zasadach, z poszanowaniem polskiej specyfiki na drodze do budowy socjalizmu. Przedstawiciele „puławian” zajmowali kluczowe stanowiska w aparacie propagandowym PRL, co miało decydujące znaczenie dla treści przekazywanych przez propagandę w okresie polskiego Października. Wielu działaczy tej frakcji było wcześniej odpowiedzialnych za wprowadzanie stalinowskiego terro$\mathrm{ru}^{34}$. Dlatego ze względu na ich przeszłość w aparacie władzy głównym zarzutem stawianym „puławianom” przez przeciwników i część historyków był koniunkturalizm. Wynikał on z chęci uniknięcia kary poprzez wspieranie reform, aby od-

\footnotetext{
33 A. Werblan, Październik 1956..., s. 20-21.

${ }^{34}$ Ibidem, s. 21-22.
} 
wrócić uwagę społeczeństwa od problemu odpowiedzialności za zbrodnie stalinowskie i pozostać w kierownictwie partyjnym ${ }^{35}$.

Trudno dziś powiedzieć, na ile poglądy deklarowane przez działaczy PZPR były ich głębokimi przekonaniami, a na ile stanowiły element strategii obliczonej na przetrwanie w partii. Maria Dąbrowska w Dziennikach powojennych zauważyła już w 1954 r., pisząc o przedstawicielach najwyższych władz PRL, że „ludzie "kasty kapłańskiej" radzi kpią sobie z rzeczy "narodowi do wierzenia podawanych". Że lekceważą sobie swoich najlepszych służków" ${ }^{\prime 36}$. Autorka wielokrotnie podkreśla, że wielu propagatorów reform 1956 r. to dawni zatwardziali stalinowcy, którzy z różnych względów zmienili poglądy ${ }^{37}$, albo że dawni stalinowcy zmienili się w najaktywniejszych przeciwników ZSRR. Uznała to nawet za naturalną u komunistów „reakcję złego sumienia po popełnionych błędach"38.

W efekcie konfrontacji między frakcjami i pod okiem Nikity Chruszczowa, przybyłego do Warszawy na pogrzeb Bieruta, dokonano wyboru kompromisowego kandydata na stanowisko I sekretarza KC PZPR. Został nim Edward Ochab, wybrany podczas VI plenum KC 20 marca 1956 r. Ku zaskoczeniu wszystkich Ochab zainicjował politykę liberalizacji, wzmacniając tym samym ,puławian”.

W kolejnych miesiącach doszło do zmian kadrowych w partii i w aparacie bezpieczeństwa. Część najbardziej skompromitowanych funkcjonariuszy, w tym Jakub Berman, została zwolniona z zajmowanych stanowisk. Niektórych aresztowano. Personel służby bezpieczeństwa zredukowano o 22\% ${ }^{39}$. W kwietniu 1956 r. Sejm uchwalił ustawę o amnestii. Objęte nią zostały osoby skazane za przestępstwa „przeciwko władzy ludowej”. W ramach amnestii karę śmierci zamieniono na 15 lat więzienia, dożywocie natomiast na 12 lat. Do czerwca 1956 r. zaś uwolniono z więzień 28 tys. osób skazanych za przestępstwa polityczne ${ }^{40}$.

Na początku 1956 r. mogło się zdawać, że Moskwa skłonna jest tolerować reformy systemu. W ramach proponowanej przez Chruszczowa zasady mieściły się normalizacja stosunków i współpraca z zaciekle zwalczaną poprzednio Jugosławią, a nawet nowa koncepcja przechodzenia do socjalizmu na drodze parlamentarnej, nie zaś wyłącznie wskutek rewolucji, jak proponowano dotychczas. Dla państw satelickich był to znak, który mógł wskazywać, że pod rządami Chruszczowa znacznie poszerzone zostały granice tolerancji wobec odmienności polity-

35 Zob. np. Paweł Wieczorkiewicz, Władysław Gomułka 1905-1982, [w:] Andrzej Szwarc, Marek Urbański, Paweł Wieczorkiewicz, 100 postaci, które tworzyły historię Polski, Świat Książki, Warszawa 2002, s. 426.

${ }_{36}$ M. Dąbrowska, Dzienniki powojenne..., t. 2, s. 423.

37 Eadem, Dzienniki powojenne ..., t. 3, s. 37-38, 70, 175, 201.

38 Ibidem, s. 218.

39 W. Roszkowski, Historia Polski..., s. 233.

${ }^{40}$ Ibidem, s. 233-234. 
ki prowadzonej przez kraje demokracji ludowej. Jednocześnie informacje o potępieniu kultu jednostki podczas zjazdu mogły stwarzać nadzieje na radykalny zwrot w polityce Moskwy.

W dalszych zmianach w propagandzie partyjnej słychać było echa XX zjazdu. Już na początku 1956 r. Biuro Prasy KC PZPR w notatce do sekretarzy wojewódzkich i redaktorów naczelnych zalecało, by omówić przełomowe znaczenie zjazdu, podkreślając przy tym krytykę błędnych metod w polityce PZPR. Oczywiście krytyka ta nie mogła podważać autorytetu partii. Stwierdzono też, że „należy wykazać, że marksistowski ruch rewolucyjny sam rodzi siły, które zdolne są odrzucić nawarstwione zło przeszłości”’"11. Prasa zaczęła też zwracać większą uwagę na zachodzące wówczas przełomowe - jak się wydawało - wydarzenia w Chinach.

Dnia 16 czerwca „Trybuna Ludu” zamieściła streszczenie przemówienia kierownika Wydziału Propagandy KC KPCh Lu Dingyi, wygłoszonego 26 maja na zebraniu chińskich uczonych, pisarzy i artystów, w którym znalazły się bardzo rewolucyjne jak na owe czasy stwierdzenia. Jak donosiła gazeta, Lu powiedział, że partia wypowiada się za wolnościa myśli w dziedzinie literatury, sztuki oraz badaniach naukowych, za wolnościa dyskusji, pracy twórczej i wolnościa krytyki, wolnościa wypowiadania i obrony pogladów na dyskutowane zagadnienia $a^{42}$. Przemówienie wiązało się z rozpoczęciem w Chinach nowej kampanii znanej jako kampania stu kwiatów. Zainicjował ją sam Mao Zedong we wcześniejszych niepublikowanych przemówieniach: O 10-ciu wielkich zależnościach (z 27 kwietnia) i Niech zakwitnie sto kwiatów, niech rywalizuje ze soba sto szkót (z 2 maja 1956 r. ${ }^{43}$. W jej trakcie zachęcano, głównie intelektualistów i studentów, do dyskusji, a nawet do krytykowania błędów partii. Towarzyszyło temu rozluźnienie cenzury i ogromne ożywienie intelektualne. Jak się wtedy wydawało, kampania stu kwiatów zmierzała do liberalizacji polityki chińskiej.

We wrześniu wiele miejsca $\mathrm{w}$ prasie polskiej poświęcono odbywającej się pierwszej sesji VIII zjazdu KPCh. To właśnie po powrocie do Warszawy ze zjazdu Edward Ochab - na zamkniętych naradach - twierdził, że w sprawie polskich przemian można liczyć na chińskie poparcie. Informacja Ochaba stanowiła bodziec dla wielu działaczy, w tym dla premiera Józefa Cyrankiewicza, do angażowania się na rzecz przemian ${ }^{44}$. W zaistniałej sytuacji przywódcy partii postanowili przekazać kierownictwo w ręce Władysława Gomułki, uważanego za jedynego człowie-

${ }^{41}$ Do sekretarzy KW i redaktorów naczelnych, Archiwum Akt Nowych, 237/XIX-68, s. 2-4.

${ }^{42}$ Polityka Komunistycznej Partii Chin w sprawach literatury, sztuki i nauki, „Trybuna Ludu”, 16 czerwca 1956, s. 4.

${ }^{43}$ Roderick MacFarquhar, The Origins of The Cultural Revolution, t. 1: Contradictions among the People 1956-1957, Columbia University Press, New York 1974, s. 48-56.

44 W. Roszkowski, Historia Polski..., s. 235. 
ka cieszącego się wystarczającym poparciem obywateli, aby móc uspokoić narastające niepokoje społeczne. Niestety nie miał on wielkich szans - jako rzekomy komunista-nacjonalista - na uzyskanie akceptacji Chruszczowa.

Stanowisko chińskie w sprawie budowy socjalizmu stało się bardzo istotne dla zwolenników reform w PZPR. Reformy polskie budziły bowiem zaniepokojenie w innych krajach socjalistycznych już na początku czerwca 1956 r. Jak wspomina Maria Dąbrowska, władze NRD ograniczały w tym czasie możliwość wyjazdu swych obywateli do Polski i ostrzegały, że w PRL, ,niektóre rzeczy posunięto za daleko i że w Niemczech to nie jest możliwe" ${ }^{45}$. Jeśli zatem tak znaczący członek wspólnoty socjalistycznej jak Chiny obierał drogę reform, uznali oni, że podobne przemiany w Polsce mogą być tolerowane przez Moskwę, a co za tym idzie przez pozostałe kraje obozu.

Znaczenie poparcia ze strony Chin Ludowych wydaje się jeszcze ważniejsze, gdy weźmie się pod uwagę postawę państw zachodnich wobec sytuacji w Polsce. 28 czerwca rozpoczęły się w Poznaniu starcia robotników z milicją. Ich bezpośrednią przyczyną był brak pozytywnej reakcji władz na żądania pracownicze wysunięte miesiąc wcześniej. Rozruchy były o tyle znaczące, że miały miejsce w czasie Międzynarodowych Targów Poznańskich. Informacje o nich trafiły więc na Zachód dzięki obecnym na targach dziennikarzom i wystawcom niemal z całego świata.

Kraje Zachodu nie były jednak skłonne do zajmowania stanowiska w sprawie polskiej, obawiały się bowiem załamania kontaktów z Kremlem, które znacznie się polepszyły za rządów Chruszczowa. Anne Deighton twierdzi na przykład, że brytyjskie Ministerstwo Spraw Zagranicznych postanowiło nakłaniać media do ograniczania informacji z Polski, aby nie wywoływać zbytniej sensacji i podkreślać, że zamieszki w Poznaniu stanowią wewnętrzną sprawę Polski, w którą żadne państwo nie powinno ingerować ${ }^{46}$. Według Douglasa Selvage’a w Ameryce strach przed wojną nuklearną zmusił administrację prezydenta Dwighta Eisenhowera do odstąpienia od haseł „zbrojnego wyzwolenia Europy Wschodniej”, lansowanego podczas kampanii wyborczej 1952 r. Oznaczało to faktycznie powrót do ,polityki powstrzymywania” propagowanej przez administrację Harry'ego Trumana. Pierwszym wyrazem zmiany kursu w amerykańskiej polityce był brak reakcji na powstanie robotnicze w NRD w roku $1953^{47}$.

Uchwały VIII zjazdu KPCh miały rewolucyjny charakter i mogły wskazywać, że polscy reformatorzy nie są osamotnieni w procesie liberalizacji socjalizmu. Nic

${ }^{45}$ M. Dąbrowska, Dzienniki powojenne..., t. 3, s. 123.

46 Anne Deighton, Brytyjskie reakcje na wydarzenia $w$ Polsce $w$ okresie od czerwca do listopada 1956 roku, [w:] J. Rowiński (red.), Polski październik 1956..., s. 243.

${ }^{47}$ Douglas E. Selvage, Wskrzeszenie polityki wypierania: administracja Eisenhowera a polski październik 1956 roku, [w:] J. Rowiński (red.), Polski październik 1956..., s. 211-234. 
więc dziwnego, że w polskiej prasie bardzo szczegółowo relacjonowano obrady. Trzeba dodać, że poprzedni, VII zjazd odbył się w kwietniu 1945 r., jeszcze przed zwycięstwem KPCh w wojnie domowej ${ }^{48}$. W prasie polskiej cytowano na przykład Liu Shaoqi, który powiedział: „Partia stoi na stanowisku, że należy podjąć kroki mające na celu zlikwidowanie kary śmierci"49.

Na zjeździe potępiono zarówno ,prawicowe”, jak i „lewicowe” odchylenie od generalnej linii partii w okresie przejściowym. Za „prawicowe” odchylenie uznano wstrzymywanie przeobrażeń socjalistycznych w rolnictwie i przemyśle, czyli kolektywizacji i przechodzenia do systemu państwowo-prywatnego. „Lewicowe" odchylenie przejawiało się w tym, że domagano się osiągnięcia socjalizmu z dnia na dzień, żądano zastosowania metod wywłaszczenia, aby wyeliminować burżuazję narodową jako klasę, lub też zdławienia w jakiś sposób kapitalistycznego przemysłu i handlu oraz zmuszenia go do bankructwa.

Liu Shaoqi stwierdził na zjeździe: Stoimy na stanowisku, że prowadzić należy politykę dtugotrwatego wspótistnienia $i$ wzajemnej kontroli między partia komunistyczna a partiami demokratycznymi. Baza społeczna chińskich partii demokratycznych jest burżuazja narodowa, górne warstwy drobnomieszczaństwa oraz wywodzaca się z tych klas inteligencja ${ }^{50}$.

Partie demokratyczne powinny zatem podlegać kontroli KPCh, ale również partia komunistyczna powinna korzystać z kontroli i krytyki „partii demokratycznych i bezpartyjnych demokratów", gdyż w jej pracy istnieją i będą istnieć niedociągnięcia. Liu postulował też wzmocnienie kontroli Ogólnochińskiego i prowincjonalnych Zgromadzeń Przedstawicieli Ludowych nad organami administracji, wzmożenie oddolnej krytyki w partii i popieranie sygnałów płynących od mas. Jak powiedział: „Ci, którzy zamykają usta ludziom wyrażającym uwagi krytyczne lub też mszczą się na nich, powinni być należycie ukarani"s1.

Wydawało się, że przewodniczący delegacji radzieckiej goszczącej na zjeździe wyraził poparcie Moskwy dla „chińskiej odmienności”, stwierdzając: Marksizm to nie dogmat, lecz żywa nauka, która w procesie rozwoju dziejów ludzkości sprawdzana jest $w$ swoich szczególach, uzupetniana, wzbogacana i rozwijana na podstawie doświadczeń walki klasy robotniczej ${ }^{52}$.

48 Siedem Zjazdów KP Chin, „Trybuna Ludu”, 15 września 1956, s. 6.

49 VIII Zjazd KP Chin rozpocząt obrady. Przemówienie Mao Tse-tunga, Referat Liu Szao-tsi, „Trybuna Ludu”, 17 września 1956, s. 1.

${ }^{50}$ Referat polityczny KC Komunistycznej Partii Chin wygłoszony przez tow. Liu Szao-tsi na VIII Zjeździe, „Trybuna Ludu”, 18 września 1956, s. 4.

${ }^{51}$ Ibidem.

${ }^{52}$ Nigdy nikomu nie uda się zachwiać jedności i solidarności komunistów. Przemówienie tow. A. Mikojana na VIII Zjeździe KP Chin, „Trybuna Ludu”, 19 września 1956, s. 3. 
Już wtedy jednak widoczne były pewne oznaki rodzącego się konfliktu między Moskwą a Pekinem. Obok Edwarda Ochaba z przywódców partii komunistycznych bloku wschodniego obecni jedynie byli Walter Ulbricht z NRD, Gheorghe Gheorghiu-Dej z Rumunii i Enwer Hodża z Albanii. Większości delegacji przewodniczyli sekretarze KC, a Związek Radziecki reprezentował wicepremier Anastas Mikojan ${ }^{53}$. Ponadto nie wszyscy członkowie delegacji zagranicznych wzięli udział w obchodach siódmej rocznicy powstania ChRL 1 października. Pojawiły się nawet głosy świadczące o jakichś rozbieżnościach wśród partii komunistycznych, a „Trybuna Ludu” cytowała wypowiedź gościa reprezentującego na zjeździe Francuską Partię Komunistyczną. Stwierdził on, że nie sprawdziły się nadzieje tych, którzy liczyli na osłabienie jedności partii komunistycznych, a obecność licznych delegacji zagranicznych na zjeździe KPCh jest oznaką umacniania się jedności światowego ruchu komunistycznego ${ }^{54}$.

Znacząca była przytaczana przez „Trybunę Ludu” wypowiedź delegata z Włoch, który przedstawiając swoje obserwacje chińskiej sceny politycznej, stwierdził: Tym, którzy opowiadaja się przeciwko wszelkiej wspólnej akcji z komunistami, oskarżajac ich o to, że dziś pragna demokracji, a jutro ja zniszcza, oraz o to, że pragna podjać wspólne akcje z innymi partiami, by później je zlikwidować i ustanowić swa dyktaturę - będziemy mogli odpowiedzieć, powołując się na wasze doświadczenia, które zadaja kłam tym oskarżeniom ${ }^{55}$.

W zamieszczonym przez „Trybunę Ludu” streszczeniu referatu Deng Xiaopinga dotyczącego nowego statutu KPCh również podkreślano stwierdzenia na temat przestrzegania przez partię , "linii mas”. Według mówcy partia powinna wsłuchiwać się w głos mas, zbierać prezentowane przez nie idee, analizować je i systematyzować, a następnie popularyzować wśród mas. Jednocześnie partia powinna sprawdzać słuszność tych idei na podstawie działalności mas. Jak powiedział dalej Deng: Takie pojmowanie partii równoznaczne jest ze stwierdzeniem, że partia nie ma prawa wywyższać się ponad masy ludowe, że partia nie ma prawa występować wobec mas ludowych w roli łaskawej dobrodziejki, brać na siebie cała prace, zajmować się tylko administrowaniem, że partia nie ma prawa działać jak nieokietznany despota stojacy ponad masami ${ }^{56}$.

W przemówieniu podkreślone zostało, że partia poprzez wprowadzenie nowego statutu będzie promować ideę demokracji wewnątrzpartyjnej i kolektywnego

${ }^{53}$ Delegacje bratnich krajów na Zjeździe KPCh, „Trybuna Ludu”, 18 września 1956, s. 4.

${ }^{54}$ Dyskusja na Zjeździe KP Chin. Pozdrowienia od bratnich partii komunistycznych, „Trybuna Ludu", 20 września 1956, s. 1.

${ }^{55}$ Ibidem.

${ }^{56}$ O zmianach w statucie KP Chin. Fragmenty referatu tow. Teng Siao-pinga na VIII Zjeździe, „Trybuna Ludu”, 21 września 1956, s. 3. 
kierownictwa. Powinna zarazem zostać zapewniona swoboda krytyki i dyskusji. Odnosząc się do obowiązków członków KPCh, Deng Xiaoping powiedział: Niektórzy członkowie partii, majacy pewne zastugi i zajmujacy odpowiedzialne stanowiska, rzeczywiście uważaja, że wszystko im wolno, że sq to ich „przywileje”, a w pewnej części organizacji partyjnych godza się w milczeniu na podobne poglady. [...] Ludzie, którzy zachowują się „po pańsku”, uważaja, że partia nie może bez nich się obejść; $w$ rzeczywistości zaś sprawa przedstawia się wręcz przeciwnie, partii naszej nie tylko nie sa potrzebni tacy „,panowie”, lecz uważa ona nawet za niemożliwe pozostawanie ich w szeregach partii, ponieważ nie wykonuja oni, jak to czynia pozostali komuniści, obowiązków członków partii ${ }^{57}$. Zgodnie z tą sugestią w nowym statucie KPCh znalazło się wyraźne stwierdzenie, że każdy członek organizacji, bez względu na jego pozycję i zasługi, jest zobowiązany do przestrzegania statutu ${ }^{58}$.

Do nowego statutu KPCh włączono zapis mówiący, że partia opowiada się za zasadą pokojowego współistnienia państw o różnych systemach politycznych. Stanowiło to wyraz poparcia dla polityki odprężenia zainicjowanej przez Chruszczo$\mathrm{wa}^{59}$. W uchwale politycznej zjazdu natomiast wyrażono zdecydowane poparcie dla zasady „niech kwitną obok siebie kwiaty różnych pór roku”. Wiele mówiło się w niej ponadto o idei kolektywnego kierownictwa ${ }^{60}$.

Podsumowując to, co zostało powiedziane na zjeździe w sprawach zarówno stosunków z prywatnym kapitałem, jak i zasady linii mas oraz demokracji wewnątrzpartyjnej, „Trybuna Ludu” stwierdzała: W tych dniach czuliśmy wszyscy, że w dalekich Chinach omawia się i rozstrzyga sprawy niezwykle nam bliskie - wspólne. VIII Zjazd KPCh stat się drugim kamieniem milowym na drodze do odrodzenia i odnowy rewolucyjnego ruchu robotniczego. Odrodzenia i odnowy, które zapoczątkowat tak potężnie XX Zjazd Komunistycznej Partii Zwiąku Radzieckiego. Zradościa przystuchiwaliśmy się również w Chinach pochodowi tego n o w e g o, które z trudem i w bólach-jak wszystko, co nowe - rodzi się i w naszej Ojczyźnie. I które jest nieodwracalnym $\mathrm{k}$ i e r u $\mathrm{n}$ i e m ro z w o j o w y m socjalizmu w calym świecie ${ }^{61}$.

W wyniku postanowień podjętych na zjeździe władza samego Mao Zedonga jako przewodniczącego została ograniczona przez powołanie czterech wiceprzewodniczących i sekretarza partii. Ze statutu KPCh wykreślono stwierdzenie mówiące, że podstawą działania KPCh jest „myśl Mao Zedonga”. Prowadzący zjazd

57 Ibidem.

${ }_{58}$ Nowy Statut Komunistycznej Partii Chin (streszczenie), „Trybuna Ludu”, 28 września 1956, s. 2.

59 Ibidem.

${ }^{60}$ Socjalizm w Chinach - w zasadzie zbudowany. Uchwała polityczna VIII Zjazdu KP Chin, ,Trybuna Ludu", 29 września 1956, s. 2.

${ }^{61} W$ dalekich Chinach o sprawach bliskich, „Trybuna Ludu”, 1 października 1956, s. 1. 
Liu Shaoqi i Deng Xiaoping wyraźnie opowiadali się za polityką Chruszczowa i za zasadą kolektywnego kierownictwa. Stwierdzili ponadto, że Chiny nigdy nie ulegną kultowi jednostki. W wyniku zjazdu pozycja Mao Zedonga jako przywódcy partii komunistycznej i narodu chińskiego została zatem wyraźnie osłabiona.

Postanowienia VIII zjazdu nie zostały jednak wprowadzone w życie. Przeniesienie na grunt chiński zainicjowanego przez Chruszczowa procesu destalinizacji stanowiło o wiele trudniejsze wyzwanie niż przeprowadzenie go w samym ZSRR. Mao był zarazem Leninem i Stalinem chińskiej rewolucji. Niemożliwe wydawało się wtedy osłabianie autorytetu Mao w imię walki z kultem jednostki bez podważania fundamentów władzy partii komunistycznej. Dlatego właśnie wpływ XX zjazdu KPZR na pozycję przewodniczącego KPCh był ograniczony. Mao sam planował stopniowe usuwanie się na drugi plan życia politycznego, żeby uniknąć w Chinach walki o władzę podobnej do tej, która miała miejsce w ZSRR. Utworzenie funkcji honorowego przewodniczącego miało umożliwić mu realizację tego planu. Faktycznie Mao Zedong zrezygnował z funkcji przewodniczącego ChRL - w związku z krytyką jego polityki - na konferencji Biura Politycznego w lipcu 1959 r. w Lushanie. Peng Dehuai, który najostrzej go krytykował, został jednak także w ramach kompromisu pozbawiony funkcji ministra obrony i wszystkich stanowisk. Rezygnacja z funkcji rzeczywistego przywódcy partii i przyjęcie godności honorowego przewodniczącego miało nastąpić na następnym planowanym zjeździe w roku $1961^{62}$. Nigdy jednak do tego nie doszło. Wręcz przeciwnie, ,rewolucja kulturalna" doprowadziła w latach 1966-1969 do zupełnego podporządkowania całej partii Mao oraz jego radykalnym zwolennikom i do usunięcia jego oponentów.

Zainicjowanie w Chinach polityki stu kwiatów, uchwały VIII zjazdu KPCh, a także prowadzenie przez ten kraj bardziej samodzielnej polityki wobec Moskwy sprawiły, że począwszy od maja 1956 r., polska prasa poświęcała mu dużo miejsca. Biorąc pod uwagę, że wielu ,puławian” związanych było z prasą i aparatem propagandowym PZPR, można przypuszczać, że doniesienia z Chin miały przekonać niezdecydowanych członków aparatu partyjnego do poparcia idei reform. $\mathrm{Z}$ jednej strony wskazywano, że istnieje socjalizm w formie bardziej liberalnej niż ten znany w Polsce z lat minionych. $Z$ drugiej, że liberalna wersja socjalizmu wspierana jest we wspólnocie państw socjalistycznych przez członka na tyle znaczącego, że musi się z nim liczyć nawet Związek Radziecki. Można więc powiedzieć, że poświęcanie tak dużej uwagi sprawom reform chińskich stanowiło część kampanii propagandowej, która doprowadziła do polskiego Października 1956 r.

${ }^{62}$ R. MacFarquhar, The Origins..., t. 1, s. 10, 105-107. 


\section{Znaczenie polityki ChRL dla przemian polskiego Października 1956}

Zmiany, jakie zaszły w Polsce po Październiku 1956 r., były ewenementem w skali całego bloku komunistycznego. Choć często piszący o nich z perspektywy współczesnej nie dostrzegają ich skali, to w ówczesnej rzeczywistości stanowiły one rewolucyjny przełom. Na początku lat 50. Polska znajdowała się pod ścisłą kontrolą ZSRR. Kontrola ta była sprawowana zarówno przez ambasadę tego kraju, jak i przez licznych doradców radzieckich, przejmujących rolę decydentów, umieszczonych na wszystkich szczeblach administracji cywilnej i wojskowej. Resort obrony znajdował się w rękach przysłanego przez Moskwę marszałka Konstantego Rokossowskiego, który był też wpływowym członkiem Biura Politycznego KC PZPR. Ponadto w kluczowych ośrodkach decyzyjnych armii umieszczono wielu oficerów radzieckich ${ }^{63}$. Dominacja sowiecka przejawiała się w procesie tworzenia prawa ${ }^{64}$, a nawet w pogardliwym stosunku Stalina do polskich przywódców ${ }^{65}$. W okresie tym partia miała wpajać robotnikom ich klasową świadomość i internacjonalizm, natomiast wątki patriotyczne i narodowe pomijano. Z tej funkcji wynikała struktura PZPR, w której instytucje działały na zasadzie hierarchicznej podległości, a nie odpowiedzialności przed wybieralnymi organami. Władzę sprawowała wąska grupa działaczy wspieranych przez aktywistów, którzy zgłębili ideologię i rozumieli w swym mniemaniu „obiektywne interesy klasy robotniczej”66.

W październiku $1956 \mathrm{r}$. Moskwa musiała się zgodzić na wycofanie swych doradców, do tego na tolerowanie polskiej odmienności w ramach bloku komunistycznego i pewnej niezależności w sprawach polityki zarówno wewnętrznej, jak i zagranicznej. Wiązało się to z uznaniem narodowego charakteru komunizmu w Polsce zamiast dotychczasowego lansowania „nadrzędności interesów wielkiej ojczyzny proletariatu" nad interesami narodowymi ${ }^{67}$. Po 1956 r. Polska stała się jedynym krajem bloku, gdzie w rolnictwie dominowała własność prywatna, a także gdzie tolerowano prywatny handel i rzemiosło. Ograniczono kompetencje aparatu represji i wprowadzono elementarne zasady praworządności ${ }^{68}$. Również - mimo różnych szykan - Kościół katolicki cieszył się tu największą swobodą. Nastąpiło otwarcie na Zachód w sferze kultury i nauki. W sztuce prawie całkowicie zanikł

${ }^{63}$ Andrzej Friszke, Polski październik 1956 roku z perspektywy pięćdziesięciolecia, [w:] J. Rowiński (red.), Polski październik 1956..., s. 305-324.

${ }^{64}$ A. Friszke, Polska. Losy państwa i narodu 1939-1989, Iskry, Warszawa 2003, s. 181.

${ }^{65}$ Paweł Wieczorkiewicz, Bolestaw Bierut 1892-1956, [w:] A. Szwarc, M. Urbański, P. Wieczorkiewicz, 100 postaci..., s. 405.

${ }^{66}$ A. Friszke, Polska. Losy państwa ..., s. 166.

${ }^{67}$ Włodzimierz Borodziej, Rok 1956 jako cezura whistorii polityki zagranicznej PRL, [w:] J. Rowiński (red.), Polski październik 1956..., s. 325-342.

${ }^{68}$ A. Friszke, Polska. Losy państwa..., s. 233. 
socrealizm. Miały też miejsce masowe rehabilitacje członków Armii Krajowej represjonowanych w okresie stalinowskim ${ }^{69}$. Dla mieszkańców sąsiednich krajów nauka języka polskiego stawała się często jedynym sposobem dotarcia do informacji ze świata i do nowych prądów w zachodniej kulturze ${ }^{70}$.

Zmiany październikowe nie tylko uczyniły z Polski najbardziej liberalny wówczas kraj bloku państw komunistycznych, ale i zapoczątkowały ogromne przemiany w świadomości zarówno obywateli, jak i elit PRL. Jak twierdzi Andrzej Friszke, „działo się tak dlatego, że rządzący, rezygnując z terroru jako narzędzia sprawowania władzy, stali się w pewnym stopniu wrażliwi na nastroje i opinie społeczne"71.

Przejęcie władzy w PZPR przez Władysława Gomułkę miało bardzo burzliwy przebieg, a stanowisko Chruszczowa w tej sprawie - przynajmniej na początku było zdecydowanie negatywne. Relacje na temat przebiegu zdarzeń są też bardzo różne. Świadczą one, jak dużym zniekształceniom podlegały informacje o tym kluczowym dla przyszłości Polski - a być może i całego świata komunistycznego - wydarzeniu.

Dnia 12 października na posiedzeniu Biura Politycznego wyznaczono termin VIII plenum KC na 19 października. Plenum miało dokonać zmian w kierownictwie PZPR. Na wieść o tym Chruszczow zażądał odroczenia terminu i wezwał do rozmów z KPZR, na co nie zgodził się Ochab. Odmowa udziału w konsultacjach stanowiła naruszenie zasady, zgodnie z którą wszystkie ważniejsze zmiany w kierownictwie państw satelickich są uzgadniane z Kremlem. Równie niepokojącym dla Kremla sygnałem był konflikt między Ochabem a Rokossowskim dotyczący obecności w polskiej armii oficerów radzieckich. Do Moskwy docierały też informacje o ożywionej dyskusji zarówno w kręgach inteligencji, jak i wewnątrz PZPR na temat konieczności reform. W opinii przywódców ZSRR dyskusje te i fakt tolerowania ich przez władze partyjne stanowiły zagrożenie dla socjalizmu i stosunków polsko-radzieckich ${ }^{72}$. Przejawem negatywnego nastawienia Kremla do wydarzeń nad Wisłą była kampania krytyki wobec Polski prowadzona przez prasę radziecką.

Ponieważ wydarzenia w Polsce mogły ograniczyć kontrolę Moskwy nad Warszawą, przywódcy KPZR próbowali wymusić na kierownictwie PZPR wstrzymanie planowanych zmian w partii. Niepokój Moskwy podsycały informacje, że z Biura Politycznego mają być usunięci prawie wszyscy czołowi „natolińczycy” oraz marszałek Rokossowski. Tuż przed rozpoczęciem VIII plenum do Warszawy

${ }^{69}$ Zob. też A. Friszke, Anatomia buntu - Kuroń, Modzelewski i komandosi, Znak, Kraków 2010, s. 19.

${ }^{70}$ Krzysztof Gawlikowski, Kluczowy moment wptywu Chin na losy Polski - przyczynek do historii stosunków polsko-chińskich, „Azja-Pacyfik” 2008, t. 11, s. 286.

${ }^{71}$ A. Friszke, Polski październik..., s. 318.

72 Aleksander Oriechow, Polska w 1956 roku widziana z Kremla i Placu Starego, [w:] J. Rowiński (red.), Polski październik 1956..., s. 59-61. 
- bez zaproszenia - przybyła radziecka delegacja z I sekretarzem KPZR Nikitą Chruszczowem na czele. Trwało jednocześnie przemieszczanie w kierunku Warszawy jednostek radzieckich stacjonujących w Polsce. Według Wojciecha Roszkowskiego zostały one wstrzymane na skutek dyskusji Chruszczowa z Ochabem przed rozpoczęciem plenum ${ }^{73}$. Roman Zambrowski wspomina, że podczas powitania radzieckiej delegacji na lotnisku Chruszczow miał wyzwać Ochaba od zdrajców, a w trakcie samych rozmów w Belwederze miało dochodzić do ostrych kłótni między Gomułką - stojącym na czele delegacji PZPR - z jednej strony a Chruszczowem i Mołotowem z drugiej ${ }^{74}$. Według Roszkowskiego prawdopodobnie w tym czasie nadeszła do Warszawy wieść o interwencji partii chińskiej, by spór rozwiązać metodami pokojowymi ${ }^{75}$. Paulina Codogni sugeruje natomiast, że informację o negatywnym stosunku Mao do szykowanej w Polsce interwencji przekazano Chruszczowowi z Moskwy podczas przerwy w rozmowach z przedstawicielami KC PZPR. Zdaniem autorki o takiej możliwości mogło świadczyć nagłe złagodzenie stanowiska Chruszczowa wobec Gomułki w dalszej części rozmów. Nie ma jednak żadnych dowodów na to, że taka informacja dotarła do Chruszczowa.

W trakcie toczących się w Belwederze rokowań i plenum KC (a także po jego zakończeniu) w całej Warszawie trwały wiece poparcia dla reform. Żądano między innymi poszerzenia demokracji, usunięcia przeciwników przemian z kierownictwa partii, z wojska zaś Rokossowskiego, a także wyjazdu z Polski wojsk radzieckich. Niektóre demonstracje miały zdecydowanie antykomunistyczny charakter. Dochodziło do zamieszek tłumionych przez milicję ${ }^{76}$.

W trakcie rozmów w Warszawie Chruszczow wstrzymał co prawda marsz wojsk na polską stolicę, znajdowały się one jednak zaledwie w odległości 50-80 kilometrów od niej. Same rozmowy miały być kontynuowane w Moskwie. Delegacja radziecka zadowoliła się tymczasowo zapewnieniem, że Polska nie wystąpi z Układu Warszawskiego. Plany dotyczące interwencji zbrojnej nie zostały jednak przez Chruszczowa całkowicie zaniechane. O ostatecznej zmianie jego decyzji zadecydowała postawa przywódców chińskich.

Wrzenie w PZPR trwało od kilku miesięcy, więc Mao Zedong zapewne wiedział o tym, co się działo w Warszawie, i znał stanowisko Moskwy w tej sprawie. Poparcie udzielone Ochabowi podczas jego wizyty w Chinach świadczy, że już

${ }^{73}$ W. Roszkowski, Historia Polski..., s. 236.

74 Roman Zambrowski, Dlaczego Gomułka i co spowodowało odwrót Gomutki, [w:] Stefan Bratkowski (red.), Październik 1956. Pierwszy wyłom w systemie. Bunt, rozsądek, młodość, Prószyński i S-ka, Warszawa 1996, s. 137, 139.

${ }^{75}$ W. Roszkowski, Historia Polski..., s. 236-237.

${ }^{76}$ A. Friszke, Polska. Losy państwa..., s. 225. 
przed VIII plenum kierownictwo KPCh zdecydowało się na poparcie zmian personalnych w PZPR ${ }^{77}$.

Chińczycy na bieżąco śledzili sytuację w Polsce. Szukali jednocześnie okazji do poznania rzeczywistych planów przywódców PZPR - zwłaszcza w toku wizyty Ochaba w Pekinie na VIII zjeździe KPCh. Komplikowała to jednak niemal stała obecność w otoczeniu Ochaba „towarzyszy radzieckich” i ich polskich sympatyków. W tej sytuacji Chińczycy w trakcie pożegnania delegacji polskiej na pekińskim lotnisku zastosowali sprytny zabieg: już po odjeździe radzieckiego ambasadora i części członków delegacji polskiej gospodarze zainscenizowali awarię samolotu. Dzięki temu Ochab mógł się spotkać sam na sam na lotnisku z wiceprzewodniczącym KC KPCh, marszałkiem Zhu De odpowiedzialnym za kontakty z Polską. Podczas spotkania miał poinformować Zhu o planowanej rehabilitacji Gomułki, planach zmian w kierownictwie PZPR i o aktualnej sytuacji w Polsce. Miał też przekazać własną ocenę wydarzeń poznańskiego Czerwca ${ }^{78}$.

Podczas VIII zjazdu KPCh sam Mao wyrażał zdecydowane poparcie dla polskiej niezależności - w rozmowach zarówno z Ochabem, jak i z Mikojanem. Spór chińsko-radziecki w tej kwestii miał doprowadzić do opuszczenia przez Mikojana Chin jeszcze przed zakończeniem obrad zjazdu. W rozmowach z Ochabem natomiast Mao wyrażał sympatię dla Gomułki ${ }^{79}$. Znamienne było też zachowanie Ochaba wobec Kremla. Przejeżdżając przez Moskwę, nie poinformował on kierownictwa radzieckiego o planach wyboru Gomułki na szefa partii, a to właśnie jego informacja o chińskim poparciu dała sygnał do sprzecznej z wolą Kremla zmiany kierownictwa PZPR ${ }^{80}$.

Zaraz po powrocie delegacji KPZR do Moskwy 20 października zebrało się Prezydium KC w celu podsumowania wizyty w Warszawie. Została wtedy podjęta decyzja o - jak to określono - „skończeniu z tym, co się dzieje w Polsce”. Po otrzymaniu wiadomości o usunięciu Rokossowskiego z Biura Politycznego Chruszczow zaczął rozważać zorganizowanie manewrów wojskowych i zastąpienie Gomułki ,tymczasowym komitetem rewolucyjnym”. Zdecydowano się też na ostrą kampanię prasową wymierzoną w polskie media za prowadzenie przez nie „antyradzieckiej propagandy” i ,podkopywanie zdobyczy socjalizmu w Polsce" 81.

Ostatecznie jednak Chruszczow zaniechał interwencji zbrojnej i zlecił odwołanie radzieckich oficerów z Ludowego Wojska Polskiego ${ }^{82}$. Jak sam przyznał, na

77 K. Gawlikowski, Kluczowy moment..., s. 280-291.

78 J. Rowiński, ChRL a wydarzenia..., s. 247-248.

79 R. MacFarquhar, The Origins ..., t. 1, s. 169-170.

${ }^{80}$ K. Gawlikowski, Kluczowy moment..., s. 287-289.

${ }^{81}$ Mark Kramer, The Soviet Union and the 1956 Crises in Hungary and Poland: Reassessments and New Findings, ,Journal of Contemporary History” 1998, t. 33, nr 2, s. 172.

${ }^{82}$ A. Oriechow, Polska w 1956 roku..., s. 64. 
jego decyzję wpłynęło stanowisko Mao Zedonga. Na spotkaniu z radzieckim ambasadorem w Pekinie 22 października Mao powiedział, że aby Polska pozostała w Układzie Warszawskim, należy się zgodzić na wybór Gomułki na stanowisko I sekretarza i ułożyć z nim stosunki na nowych zasadach ${ }^{83}$, natomiast interwencja zbrojna jest przez KPCh nie do przyjęcia. W tym samym czasie na pekińskim lotnisku doszło do niezapowiedzianego spotkania odlatującego do Warszawy kierownika Wydziału Przemysłu Lekkiego KC PZPR Mieczysława Marca z trzema członkami najwyższego kierownictwa KPCh: dwoma wiceprzewodniczącymi KC - Liu Shaoqi i Zhu De oraz z sekretarzem generalnym KC KPCh Deng Xiaopingiem. Przekazali oni wyrazy poparcia dla nowych władz PZPR i zapowiedzieli udzielenie Polsce pomocy gospodarczej. Spotkanie dostojników tak wysokiego szczebla z Marcem - wbrew ściśle przestrzeganym w Chinach zasadom hierarchii-stanowiło manifestację zdecydowanego poparcia dla nowego kierownictwa polskiej partii ${ }^{84}$.

W dniach 23-30 października toczyły się w Moskwie rozmowy z udziałem przedstawicieli NRD, Czechosłowacji, Bułgarii i Chin dotyczące sytuacji w Polsce. W delegacji ChRL znajdowali się Liu Shaoqi i Deng Xaoping. To właśnie w trakcie tej narady Chruszczow przyznał chińskim przedstawicielom, że jego stanowisko w sprawie Polski i Gomułki było niewłaściwe, dlatego postanowił je zmienić po zapoznaniu się z oceną strony chińskiej ${ }^{85}$. Trudno jednak powiedzieć, kiedy w istocie podjął decyzję o zaniechaniu interwencji. Trzeba dodać, że stanowisko chińskie w sprawie Polski było bardzo zdecydowane. Członkowie chińskiej delegacji podkreślali, że wydarzenia w Polsce są skutkiem „wielkomocarstwowej postawy” Moskwy, a jedynym sposobem poprawy wzajemnych stosunków jest przezwyciężenie tej postawy ${ }^{86}$. Sam Mao Zedong twierdził, że zarówno przywódcy ZSRR, jak i członkowie obecnych w Moskwie delegacji NRD, Bułgarii i Czechosłowacji opowiadali się za interwencją. Od delegacji chińskiej oczekiwano natomiast jedynie akceptacji tej decyzji ${ }^{87}$. Ostatecznie w czasie narady 24 października wojska radzieckie znajdujące się w okolicach Warszawy otrzymały rozkaz powrotu do koszar.

Trzeba tu jeszcze zwrócić uwagę na częste wyrazy wdzięczności składane przez przedstawicieli władz PRL Chińczykom za „uratowanie polskich reform”. Gdyby nie były one oparte na faktach, niewątpliwie doszłoby do nacisków Moskwy w celu zdementowania takich wypowiedzi, gdyż to ona miała monopol na wszelkie „,dobrodziejstwa” czynione krajom socjalistycznym. Do żadnych nacisków za-

${ }^{83}$ Shen Zhihua, Li Danhui, Kryzys w Polsce 1956 roku i stosunki polsko-chińskie widziane z Pekinu, [w:] J. Rowiński (red.), Polski październik 1956 ..., s. 90.

${ }_{84}$ J. Rowiński, ChRL a wydarzenia ..., s. 250-251.

${ }^{85}$ Shen Zhihua, Li Danhui, Kryzys w Polsce..., s. 92.

86 J. Rowiński, ChRL a wydarzenia ..., s. 276.

${ }^{87}$ W.J. Dziak, J. Bayer, Mao ..., s. 98-99. 
pewne jednak nie doszło, ponieważ wątek ten długo przewijał się w wystąpieniach przedstawicieli polskich władz ${ }^{88}$.

Z relacji przywódców Polski Ludowej na temat ich stosunku do ChRL na początku 1956 r. wynika, że zdawali oni sobie sprawę z wyjątkowej pozycji tego kraju w kontaktach z innymi krajami komunistycznymi i że odegrał on istotną rolę w przemianach październikowych. Edward Ochab w rozmowie z Teresą Torańską, przeprowadzonej w 1981 r., stwierdził, że jego polityka wobec Chin miała zapobiec izolacji PZPR w bloku komunistycznym. Chciał on przede wszystkim uświadomić Chińczykom, że przeprowadzając reformy, Polska zamierza pozostać krajem socjalistycznym i zachować dotychczasowe sojusze ${ }^{89}$. Według relacji Ochaba, kiedy podczas VIII zjazdu KPCh poinformował przywódców ChRL o planowanych zmianach w polskiej partii i dążeniu do bardziej równoprawnych stosunków ze Związkiem Radzieckim, gospodarze „z dużą sympatią odnieśli się do naszych spraw" ${ }^{90}$. Wspomina też o rozmowach, które kontynuowano na lotnisku w trakcie zainscenizowanej przez gospodarzy naprawy samolotu. Ochab potwierdził, że Chiny odegrały decydującą rolę w rozwiązaniu konfliktu między Warszawą a Moskwą, wywołanego wyborem Gomułki na przywódcę PZPR. Powiedział on: „Jestem przekonany, że gdyby Chiny w porę nie przysłały swego ostrzeżenia, do interwencji w Polsce by doszło..."

VIII plenum obok zmian w kierownictwie zatwierdziło radykalny jak na owe czasy program reform, chociaż - jak czytamy w uchwale końcowej - zasadniczym ich celem miało być wzmocnienie kierowniczej roli partii ${ }^{92}$. Główny nacisk położono na poprawę warunków życia i rozwój socjalistycznej demokracji. Większość zmian, jakie zapowiadała uchwała plenum, była wcześniej szeroko omawiana w prasie partyjnej jako reformy wprowadzone przez KPCh bądź przejawy specyficznej chińskiej drogi budowy socjalizmu.

W sferze gospodarczej wprowadzono wiele rozwiązań, o których wcześniej prasa partyjna rozpisywała się jako o przejawach „chińskiej odmienności”: przesunięcie znacznych środków na cele konsumpcyjne kosztem inwestycji, przemysłu zbrojeniowego i eksportu, umożliwienie osobom prywatnym otwierania małych przedsiębiorstw, sklepów i zakładów rzemieślniczych, rozwój budownictwa indywidualnego itp.

${ }^{88}$ K. Gawlikowski, Kluczowy moment..., s. 287.

89 Teresa Torańska, Oni, wydawnictwo II obiegu: Agencja Omnipress, 1989, s. 217-218.

${ }_{90}$ Ibidem, s. 219.

91 Ibidem, s. 221.

92 Uchwała VIII Plenum KC PZPR o aktywnych zadaniach politycznych i gospodarczych partii, „Trybuna Ludu”, 26 października 1956, s. 3. 
W sferze politycznej plenum postanowiło zwiększać - podobnie jak to uczyniono na I sesji VIII zjazdu KPCh - demokratyzację wewnątrz partii. W uchwale plenum czytamy: Partia musi konsekwentnie pokonywać we własnych szeregach konserwatyzm i małoduszny lęk przed nowym, kurczowe trzymanie się przestarzabych doktryn i schematów, próby cofania się i nawrotów do starych metod kierowania i rządzenia obciążonych zarówno stalinowskimi, jak i rodzimymi wypaczenia$m i^{93}$. Przypominano jednocześnie członkom partii o konieczności przestrzegania dyscypliny partyjnej oraz nakreślono jasne granice demokratyzacji i liberalizacji. Stwierdzono, że nie ma w Polsce wolności dla wrogów socjalizmu. Jasno określono, że Polska pozostaje w sojuszu ze Związkiem Radzieckim i innymi krajami socjalistycznymi, choć stosunki te mają być oparte na nowych zasadach. Jak stwierdził Gomułka w opublikowanym na łamach „Trybuny Ludu” liście do robotników i młodzieży: „W ramach takich stosunków każdy kraj winien posiadać pełną samodzielność i niezależność, a prawa każdego narodu do suwerennego rządzenia się w niepodległym kraju winny być w pełni na wzajem szanowane"94.

$\mathrm{Z}$ niezależnością $\mathrm{w}$ ramach obozu socjalistycznego wiązało się też pojęcie „własnej drogi do socjalizmu”. Podobnie jak to uczyniono w Chinach, uchwała VIII plenum KC PZPR potępiła bezmyślne kopiowanie wzorów z innych państw, a choć stawiała ZSRR za wzór, apelowała o dopasowanie procesu budowania socjalizmu do polskich warunków. Jednocześnie - w przemówieniu na placu Defilad - Gomułka uznawał konieczność stacjonowania na terytorium Polski oddziałów armii radzieckiej. Uzasadniał to potrzebą obrony Polski przed zagrożeniem ze strony Niemiec Zachodnich ${ }^{95}$.

Obraz ChRL, lansowany w propagandzie PRL od 1954 r., a zwłaszcza w ciągu kilku miesięcy poprzedzających VIII plenum, pozostawał w ścisłym związku z reformatorskimi planami frakcji, która zaczęła dominować we władzach PZPR. Uchwały plenum i deklaracje polityczne Gomułki zapowiadały z jednej strony wiele daleko idących reform, z drugiej - jak wskazywano - określały granice tych reform. Ograniczone reformy mogły zyskać poparcie Chin, które w tym czasie również dążyły do uniezależnienia się od ZSRR, a także do zwiększenia swej roli w bloku państw socjalistycznych. Jak pokazały wydarzenia na Węgrzech, Chiny nie popierały wtedy żadnych posunięć, które mogłyby zagrozić jedności państw socjalistycznych.

Mimo radzieckiej interwencji na Węgrzech (zakończonej 10 listopada 1956 r.), popartej przez Pekin, w Polsce realizowano reformatorski program Października.

93 Ibidem.

${ }^{94}$ List tow. Władysława Gomułki do robotników i młodzieży, „Trybuna Ludu”, 25 października 1956, s. 1.

95 Przemówienie towarzysza Władysława Gomułki, „Trybuna Ludu”, 26 października 1956, s. 1. 
13 listopada odwołano Konstantego Rokossowskiego z funkcji ministra obrony, co wywołało niezadowolenie zarówno w Moskwie, jak i w Pekinie ${ }^{96}$. Wkrótce kolejnych 32 oficerów radzieckich - generałów i pułkowników - zwolniono ze służby w Ludowym Wojsku Polskim i po udekorowaniu polskimi odznaczeniami odesłano do Związku Radzieckiego. Jednakże, jak stwierdza Andrzej Friszke, zmiany październikowe nie miaty naruszać zasadniczych cech ideologicznych PZPR. Nadal miała w niej dominować doktryna marksistowsko-leninowska, zasada centralizmu demokratycznego, kontrolowania przez partię życia politycznego społecznego i gospodarczego ${ }^{97}$. Wykluczone było przywrócenie demokracji wielopartyjnej. Mimo liberalizacji decydującą rolę w każdym przejawie życia kraju mieli Biuro Polityczne partii i sam Gomułka ${ }^{98}$.

Trzeba też pamiętać, że poparcie dla Gomułki ze strony Mao nie oznaczało automatycznie akceptacji całego procesu reform październikowych w Polsce. Późniejsza ewolucja systemu politycznego Chin Ludowych wskazała, że wizja komunizmu realizowana przez przywódcę KPCh miała bardzo radykalny charakter. Poparcie Gomułki służyło głównie celom polityki zagranicznej ChRL zmierzającej do realizacji własnego interesu narodowego, a szczególnie: chęci wyzwolenia się spod radzieckiej dominacji; zwiększenia roli Chin w kształtowaniu polityki obozu socjalistycznego i budowy ich autonomicznej pozycji oraz wpływów w krajach socjalistycznych; realizacji aspiracji mocarstwowych tego kraju zgodnie z ich interpretacją i wizją stworzoną przez Mao Zedonga; realizacji osobistych ambicji Mao, który uważał, że to jemu właśnie należy się przywództwo w świecie komunistycznym po śmierci Stalina; wreszcie wyzwoleniu się spod ideologicznej hegemonii Moskwy i realizowaniu własnej wizji komunizmu.

Oczywiście w interesie Chin nie leżało wtedy popieranie jakiegokolwiek procesu, który mógłby zagrozić jedności państw socjalistycznych. Dlatego właśnie - wobec deklaracji Budapesztu o wystąpieniu z Układu Warszawskiego - Pekin jednoznacznie poparł radziecką interwencję na Węgrzech. Także wsparcie przez Mao reform Gomułki stanowiło manewr taktyczny mający zwiększyć rolę ChRL w obozie państw socjalistycznych oraz autorytet Mao w chińskich środowiskach inteligenckich w trakcie kampanii stu kwiatów ${ }^{99}$. Z drugiej strony polityka Gomułki nie prowadziła do obalenia socjalizmu ani do wyjścia Polski z Układu Warszawskiego. Wydarzenia październikowe wykazały, że Chruszczow musi się liczyć ze zdaniem Pekinu, a zmiana relacji Moskwa-Warszawa stanowiła element walki Pekinu o większą samodzielność w dziedzinie prowadzonej przez siebie polityki.

\footnotetext{
96 J. Rowiński, ChRL a wydarzenia..., s. 278.

${ }^{97}$ A. Friszke, Polska. Losy państwa..., s. 228.

98 Ibidem.

99 J. Rowiński, ChRL a wydarzenia ..., s. 287.
} 
Zgodnie z wcześniejszymi ustaleniami delegacja PZPR udała się na rozmowy do Moskwy, a 18 listopada na Kremlu podpisano układ polsko-radziecki. Znalazły się w nim stwierdzenia o wzajemnym poszanowaniu, nieinterwencji i suwerenności. Przywódcy radzieccy zobowiązali się do zwiększenia liczby Polaków repatriowanych z ZSRR (co otworzyło możliwości powrotu do kraju tysiącom osób represjonowanych w różnych formach). Dzień wcześniej natomiast uregulowano status wojsk radzieckich stacjonujących w Polsce. Kreml zgodził się - przynajmniej teoretycznie - na uzgadnianie z rządem polskim liczebności i ruchów tych wojsk ${ }^{100}$. W praktyce po podpisaniu tego porozumienia pozostały w Polsce tylko duże bazy radzieckie, natomiast wiele małych oddziałów stacjonujących w różnych miejscowościach usunięto.

W następnych tygodniach nowe kierownictwo PZPR zaczęło realizować pewne postulaty społeczne. Odbyły się procesy niektórych zbrodniarzy stalinowskich. Złagodzono wyroki w sprawie wydarzeń poznańskiego Czerwca. Złagodzenie cenzury umożliwiło druk w Polsce wielu publikacji zachodnich i emigracyjnych. Władze starały się też zjednać sobie przychylność Kościoła katolickiego. Odwołano dekret o obsadzaniu stanowisk kościelnych przez władze państwowe i wydano (formalnie) zgodę na nieobowiązkowe nauczanie religii w szkołach.

Nadal w prasie stawiano Chiny za przykład rozwiązywania problemów z przechodzeniem do socjalizmu. I tak 3 listopada „Trybuna Ludu” poinformowała, że dwa dni wcześniej rząd ChRL opublikował oświadczenie w sprawie deklaracji rządu Związku Radzieckiego z dnia 30 października o podstawach rozwoju i dalszego umacniania przyjaźni między Związkiem Radzieckim a innymi państwami socjalistycznymi.

W oświadczeniu powiedziano, że stosunki te powinny opierać się na zasadach: „wzajemnego poszanowania suwerenności i integralności terytorialnej, nieingerencji w sprawy wewnętrzne, równości i wzajemnych korzyści oraz pokojowego współistnienia. Jak głosił komunikat: Rząd Chińskiej Republiki Ludowej stwierdza, że narody Polski i Węgier w toku niedawnych wydarzeń wysunęły żądania w sprawie umocnienia demokracji, niezależności i równości oraz podniesienia stopy życiowej ludności w oparciu o rozwój produkcji. Żądania te są całkowicie słuszne. Właściwe uwzględnienie tych żądań przyczyni się nie tylko do skonsolidowania systemu demokracji ludowej w tych krajach, lecz również do zacieśnienia jedności krajów socjalistycznych"101.

100 W. Roszkowski, Historia Polski..., s. 239.

101 Stosunki między krajami socjalistycznymi powinny opierać się na 5 zasadach pokojowego wspótistnienia. Oświadczenie rządu Chińskiej Republiki Ludowej, „Trybuna Ludu”, 3 listopada 1956, s. 3. 
Apelowano o oddzielenie słusznych żądań od działalności kontrrewolucyjnej, która musi być bezwzględnie zwalczana. Ponadto w oświadczeniu znalazło się stwierdzenie: Wobec zgodności ideologii i celów walki, zdarza się często, że pewne osobistości w krajach socjalistycznych zaniedbują przestrzeganie zasady równości w stosunkach wzajemnych między narodami. Bład taki jest ze swej natury błędem właściwym burżuazyjnemu szowinizmowi. Bład taki, zwłaszcza gdy popetnia go wielki kraj, pociaga za soba nieuchronnie poważne szkody dla solidarności $i$ wspólnej sprawy krajów socjalistycznych. Z tego względu czołowi przedstawiciele i członkowie naszego rządu oraz ludność całego kraju musza zawsze zachowywać czujność, aby zapobiec błędowi szowinizmu wielkonarodowego w stosunkach z krajami socjalistycznymi i innymi krajami ${ }^{102}$.

Oświadczenie to stanowiło ewidentny sprzeciw wobec nadmiernego mieszania się ZSRR w wewnętrzne sprawy innych krajów bloku wschodniego. Już 18 listopada jednak „Trybuna Ludu” donosiła, że w swym referacie na II plenum KC KPCh Liu Shaoqi powiedział: Wszystkie kraje obozu socjalistycznego powinny zacieśniać swa jedność pod przewodem ZSRR w celu przeciwstawienia się agresji imperialistów na Bliskim Wschodzie oraz ich działalności wymierzonej przeciwko obozowi socjalistycznemu ${ }^{103}$.

Poparcie interwencji na Węgrzech i przywódczej roli ZSRR w bloku komunistycznym nie były jedynymi sygnałami świadczącymi, że Pekin nie jest skłonny do popierania nazbyt daleko idącej destalinizacji w Europie Wschodniej. 31 grudnia „Trybuna Ludu” przedrukowała opublikowany dwa dni wcześniej artykuł „Renmin Ribao" Przyczynek do sprawy historycznego doświadczenia dyktatury proletariatu. Można w nim było zaobserwować nowe akcenty w podejściu Chin do zasady pokojowego współistnienia. Czytamy więc: Chociaż stale byliśmy i jesteśmy nadal zdania, że kraje socjalistyczne i kapitalistyczne powinny współdziałać w pokoju i prowadzić pokojowe współzawodnictwo, imperialiści dąża do zniszczenia nas. Dlatego nie możemy nigdy zapominać o surowej walce z wrogiem, tj. o walce klas $w$ skali światowej ${ }^{104}$. I dalej: Ci, którzy przecza istnieniu walki klas i nie przeprowadzaja różnicy między wrogiem a nami, w żadnym wypadku nie sa komunistami ani marksistami-leninistami ${ }^{105}$.

W dalszej części podkreśla się doniosłą rolę ZSRR jako wzoru dla innych krajów budujących socjalizm. W artykule przyznaje się wprawdzie, że każdy kraj ma własną specyfikę i własną drogę do socjalizmu, lecz jeśli chodzi o podstawowa

${ }^{102}$ Ibidem.

${ }^{103}$ II plenum KC Komunistycznej Partii Chin, „Trybuna Ludu”, 18 listopada 1956, s. 2.

104 Przyczynek do sprawy historycznego doświadczenia dyktatury proletariatu, „Trybuna Ludu”, 31 grudnia 1956, s. 5.

${ }^{105}$ Ibidem. 
teorię, droga Rewolucji Październikowej jest odbiciem ogólnych praw rewolucji i budownictwa na szczególnym etapie dtugiego rozwoju społeczeństwa ludzkiego. Jest to nie tylko droga stuszna dla proletariatu Związku Radzieckiego, lecz również droga, która musi przejść proletariat wszystkich krajów, aby odnieść zwycięstwo ${ }^{106}$.

W artykule sporo miejsca poświęcono ocenie Stalina. Stwierdza się tam, że jego działalność była w zasadzie słuszna, a osiągnięcia imponujące, popełniał jednak błędy w dziedzinie polityki wewnętrznej i zagranicznej, a jego arbitralne metody pracy naruszały do pewnego stopnia zasadę demokratycznego centralizmu. Jak czytamy, w stosunkach z bratnimi krajami i partiami Stalin zajmowat stanowisko internacjonalistyczne, pomagajac $w$ walce innym narodom i przyczyniajac się do wzrostu obozu socjalistycznego; jednakże w rozwiazywaniu pewnych konkretnych problemów wykazat on tendencję do wielkonarodowego szowinizmu ${ }^{107}$.

Stwierdza się jednocześnie w artykule, że błędy Stalina nie wynikały z zasad systemu socjalistycznego i nie należy „poprawiać” socjalizmu, aby je naprawić. Przeciwnie, by uniknąć błędów popełnianych przez Stalina, należy trzymać się wiernie zasady marksizmu-leninizmu i centralizmu demokratycznego. W tekście zdecydowanie potępia się opinię Chruszczowa, że możliwe jest przechodzenie do socjalizmu bez rewolucji. Wizja taka została uznana za niemożliwą do zrealizowania ze względu na agresywne poczynania imperialistów. Ponadto obok potępienia wielkonarodowego szowinizmu znalazło się w artykule potępienie nacjonalistycznych tendencji w małych krajach. Wypadki na Węgrzech określono mianem udaremnionej próby stworzenia przez imperialistów przyczółka wojennego w Europie Wschodniej.

Również podczas wizyty premiera Zhou Enlaia w Warszawie (11-17 stycznia 1957 r.) ujawniły się pewne rozbieżności między Warszawą a Pekinem. Dotyczyły one głównie stosunku do Kościoła katolickiego w Polsce, problemu kolektywizacji rolnictwa i postawy obu krajów wobec wydarzeń na Węgrzech ${ }^{108}$. Ale na początku 1957 r. wydarzenia mające miejsce w ChRL nadal inspirowały reformatorskie skrzydło w PZPR i polskie środowiska inteligenckie. Wizyta Zhou miała więc dla władz duże znaczenie propagandowe. Tym bardziej że doszło do niej przed zbliżającymi się wyborami do Sejmu (20 stycznia) i traktowano ją jako wyraz poparcia władz chińskich - realizujących politykę liberalizacji - dla nowego kierownictwa polskiej partii.

W pierwszym półroczu na skutek prowadzenia w Chinach kampanii stu kwiatów nastąpiło tam znaczne poszerzenie swobody wypowiedzi. Zauważalny był również wzrost znaczenia ChRL jako partnera gospodarczego Polski Ludowej.

\footnotetext{
106 Ibidem.

107 Ibidem.

108 J. Rowiński, ChRL a wydarzenia ..., s. 26-27.
} 
Inspiracje polityką Chin można było znaleźć nie tylko w oficjalnych publikacjach partyjnych, pobudzała ona również niekomunistycznych intelektualistów. Szeroko komentowano znaną w Polsce wersję referatu Mao Zedonga $O$ wtaściwym traktowaniu sprzeczności $w$ tonie ludu ${ }^{109}$. Autor zawarł w nim rewolucyjną w socjalistycznych realiach tezę o możliwości istnienia sprzeczności między masami pracującymi a kierownictwem partii oraz między krajami bloku komunistycznego. Jak pisał Mao, przywódcy tracą niekiedy z oczu konkretne okoliczności i potrzeby mas. Z braku znajomości sytuacji klasy robotniczej i niewsłuchiwania się w głos mas wynika biurokratyczny styl pracy. Działacze reprezentujący ten styl nie rozwiązują problemów mas, ale brutalnie tłumią ich głos, wywołując w ten sposób niezadowolenie w masach. Aby przezwyciężyć biurokratyzm, należy „opierać się na masach i rozszerzać życie demokratyczne narodu, ażeby wzmóc kontrolę mas nad przywódcami" ${ }^{110}$. Dlatego trzeba wprowadzać rozwiązania, dzięki którym masy będą mogły swobodnie wypowiadać swe opinie, a kierownictwo realizować ich postulaty, bądź - gdy są one nierealne - rzeczowo wyjaśniać swą politykę. Jeżeli zaś przywódcy popełniają błędy, muszą się do nich publicznie przyznawać. Oczywiście granicę krytyki władzy stanowiły niepodważalność ustroju socjalistycznego oraz przewodniej roli partii komunistycznej i jedność bloku państw socjalistycznych.

Poglądy prezentowane w referacie, wygłoszonym do tego przez przywódcę państwa uznawanego za współrządzące w obozie socjalistycznym, wskazywały po raz kolejny, że możliwe jest współistnienie różnych modeli socjalizmu. Model narzucany przez Moskwę nie jest zatem jedyną wykładnią marksizmu. Stanowiło to argument na rzecz ,polskiej drogi” jako mieszczącej się w ramach dominującej ideologii. Można było jednak jasno stwierdzić, że - w przypadku Polski - granicą poparcia dla reform było utrzymanie dotychczasowych sojuszy i podstawowych zasad marksizmu.

Referat przedstawiano w polskiej prasie jako wielki wkład Mao Zedonga do rozwoju myśli marksistowskiej. Jerzy Kowalewski podkreślał na łamach „Trybuny Ludu", że tezy zawarte w referacie rozwijają w znacznym stopniu koncepcję sprzeczności nieantagonistycznych w łonie społeczeństwa socjalistycznego ${ }^{111}$.

Wkrótce okazało się, że zmiany w polityce wewnętrznej Chin stanowiły konsekwencję taktyki Mao Zedonga. W ramach polityki stu kwiatów Mao zachęcał intelektualistów, niekomunistycznych działaczy politycznych i cały naród do krytykowania partii oraz do samodzielnego myślenia. Szybko jednak wyszło na jaw,

109 Mao Tse-tung, O właściwym traktowaniu sprzeczności w tonie ludu, Książka i Wiedza, Warszawa 1957.

${ }^{110}$ O sprzecznościach wewnętrznych $w$ spoleczeństwie. Artykut w dzienniku „Żenminżipao”, „Trybuna Ludu”, 17 kwietnia 1957, s. 3.

111 Jerzy Kowalewski, Czytajmy Mao Tse-tunga, „Trybuna Ludu”, 23 czerwca 1957, s. 3. 
że ta polityka w zamyśle inspiratora nie miała prowadzić do rzeczywistego pluralizmu poglądów i form wyrazu. Przyczyn zainicjowania kampanii stu kwiatów należy szukać prawdopodobnie w fermencie, jaki ogarnął KPCh po zainicjowaniu przez Mao polityki „komunistycznego przyśpieszenia”. Zbiegła się ona w czasie z próbami odchodzenia od stalinizmu w ZSRR i normowania stosunków tego kraju z państwami zachodnimi. Wskutek braku pozytywnych rezultatów kampanii kolektywizacji rolnictwa i przemysłu, a nawet pewnego spadku produkcji doszło do osłabienia pozycji Mao. Na VIII zjeździe KPCh we wrześniu 1956 r. niektórzy działacze z kierownictwa - inspirowani poczynaniami Chruszczowa - wystąpili z krytyką kultu jednostki i „nazbyt szybkiego” podążania w stronę komunizmu, czyli pośpiechu przy kolektywizacji.

Równocześnie z wystąpieniami w Polsce i na Węgrzech do strajków dochodziło w Chinach. Mao Zedong uznał, że sytuacja taka jest spowodowana polityką działaczy komunistycznych nieumiejących właściwie rozwiązywać sprzeczności w łonie ludu i oddziaływać wychowawczo na masy. Krytyka partii miała więc doprowadzić do wzmocnienia ideologii marksistowskiej, a nie do rzeczywistego pluralizmu ${ }^{112}$.

W tych warunkach przewodniczący postanowił odwołać się do elit spoza KPCh. Twierdził bowiem, że opór wobec jego polityki jest wynikiem złej woli aparatu partyjnego myślącego wyłącznie o utrzymaniu przywilejów, a krytyka z zewnątrz ten opór przełamie. Niedługo jednak w wyniku kampanii stu kwiatów zaczęły się ujawniać poglądy niezgodne z oczekiwaniami jej inicjatora. Aby więc nie dopuścić do rozprzestrzeniania się „poglądów niewłaściwych”, Mao postanowił nakreślić granice krytyki. Każdego, kto je przekroczył, musiały spotykać represje.

Kampania miała też odegrać znaczącą rolę w polityce zagranicznej Chin. Jedną z przyczyn jej zainicjowania była zapewne próba wykreowania wizerunku Chin kontrastującego z wizerunkiem ZSRR czasów stalinowskich. Mao propagował obraz Chin jako kraju, gdzie problemy społeczne rozwiązuje się w toku ogólnonarodowej dyskusji. O ile Związek Radziecki był krajem wyżej rozwiniętym, Chiny starały się zwiększyć swą atrakcyjność, przedstawiając się jako kraj o większych swobodach politycznych, większym pluralizmie i tolerancji ${ }^{113}$.

Tymczasem zainicjowana przez Mao krytyka zaczęła dotykać zarówno jego samego, jak i cały system polityczny panujący w Chinach. W kraju dochodziło do zamieszek studenckich, których uczestnicy wznosili hasła wzywające do rewolucji na wzór węgierski. Pojawiły się pogłoski o tworzeniu się oddziałów partyzanckich na wsi. W zaistniałej sytuacji nastąpiła w Chinach brutalna rozprawa z krytykami komunizmu, którą nazwano kampanią przeciwko prawicowcom. Wiele osób znikło w tajemniczych okolicznościach, wiele innych trafiło do obozów

112 Ibidem.

${ }^{113}$ W.J. Dziak, J. Bayer, Mao..., s. 72. 
pracy. Niektórych intelektualistów przeniesiono do „bardziej dla nich odpowiedniej" pracy fizycznej ${ }^{114}$.

Kampania stu kwiatów stanowiła niewątpliwie polityczną porażkę Mao Zedonga. On sam jednakże zaczął już w jej trakcie przedstawiać to niepowodzenie jako zamierzony efekt. Twierdził, że na fali liberalizacji miały się ujawnić elementy antykomunistyczne, które można potem łatwiej zniszczyć115.

Zmianie kursu w polityce wewnętrznej towarzyszyło także nowe stanowisko Chin w stosunkach międzynarodowych. Było ono - podobnie jak to miało miejsce w przypadku kampanii stu kwiatów - skutkiem niepowodzenia w lansowaniu polityki liberalizacji. Ani rząd na Tajwanie, ani Stany Zjednoczone nie zmieniły stanowiska wobec Chin Ludowych. Waszyngton nadal odmawiał nawiązania stosunków dyplomatycznych i handlowych z ChRL, a 27 maja 1957 r. rządy USA i Republiki Chińskiej (na Tajwanie) podpisały umowę o rozmieszczeniu na wyspie amerykańskich rakiet ziemia-ziemia zdolnych do przenoszenia głowic atomowych. Z drugiej strony sukcesy ZSRR w zdobywaniu kosmosu stały się podstawą do stwierdzenia Mao, że ,wschodni wiatr góruje nad zachodnim”. Polityka Chin w stosunku do Zachodu stała się więc bardziej agresywna, a z drugiej strony mniej tolerancyjna dla wszelkich ruchów osłabiających jedność krajów socjalistycznych. Wiązało się to także z manifestowanym przez Chiny krytycznym stosunkiem do różnych aspektów przemian w Polsce ${ }^{116}$. Można więc powiedzieć, że fascynacja polskich elit kampanią stu kwiatów wynikała raczej z nieznajomości chińskich realiów i polityki prowadzonej przez Mao. Mówiąc o tej polityce, trzeba pamiętać, że chiński przywódca był nie tylko ideologiem, ale i strategiem. Wiele jego decyzji zatem należy traktować raczej jako posunięcia taktyczne.

\section{Koniec reform październikowych}

Koniec 1957 r. przyniósł również w Polsce kres złudzeń co do kontynuowania reform. W październiku zlikwidowano „Po Prostu”, pismo propagujące reformę socjalizmu. Gomułka zapowiedział przełożenie zaplanowanego na grudzień zjazdu PZPR, a jednocześnie postanowiono przeprowadzić weryfikację członków partii. Faktycznie fascynacja kampanią stu kwiatów trwała w Polsce jeszcze długo po zainicjowaniu kampanii przeciwko prawicowcom i brutalnym stłumieniu fali krytyki w Chinach, gdyż inspirowała ona zwolenników reform i liberalizacji w naszym kraju. Jeszcze w czerwcu 1958 r. w dokumentach Biura Prasy KC PZPR, dotyczą-

\footnotetext{
${ }^{114}$ R. Terrill, Mao..., s. 285.

115 W.J. Dziak, J. Bayer, Mao ..., s. 76

116 R. MacFarquhar, The Origins..., s. 316-317.
} 
cych aktualnych problemów moralno-światopoglądowych w prasie PRL, można było przeczytać: „Równie szkodliwe stały się szczególne interpretacje teorii „stu kwiatów" - jako biernej zgody na swobodny rozwój wszelkich teorii kulturalnych i artystycznych bez względu na ich wartość ideową i stosunek do socjalizmu"117.

Kolejnym przejawem zmiany stanowiska Chin było wystąpienie delegacji KPCh podczas narady przedstawicieli partii komunistycznych i robotniczych w Moskwie w dniach 14-16 listopada. Jak wspomina Roman Zambrowski, na naradzie również delegacja ZSRR zaczęła prezentować o wiele bardziej dogmatyczne stanowisko. Dla Polaków sporym zaskoczeniem była jednak postawa Chińczyków, których dogmatyzm okazał się jeszcze większy od radzieckiego ${ }^{118}$. Przede wszystkim wielkim zaskoczeniem stało się przemówienie Mao Zedonga wzywającego do wojny nuklearnej z Zachodem. W deklaracji końcowej znalazły się stwierdzenia o dyktaturze proletariatu i walce między światem kapitalistycznym i socjalistycznym. Sam Gomułka, próbujący łagodzić ton uchwał, znalazł się w izolacji. Do tego zarzucono mu tolerowanie nadmiernych swobód, prywatnego rolnictwa i zbyt miękką politykę wobec Kościoła ${ }^{119}$.

W 1956 r. dominacja w prasie osób głoszących reformatorskie idee stanowiła istotny czynnik umożliwiający przeprowadzenie reform polskiego Października. Reformy te zbiegły się w czasie z zainicjowaniem kampanii stu kwiatów i reformatorskimi postanowieniami I sesji VIII zjazdu KPCh. Wysoka pozycja Chin w obozie państw socjalistycznych i ich poparcie dla zmian personalnych w PZPR oraz pewnej niezależności Polski od ZSRR sprawiły, że informacje o nich stały się kluczowe dla wspierania idei reformy socjalizmu w Polsce. Samo zaś poparcie ze strony Pekinu zadecydowało o tolerowaniu reform październikowych przez Chruszczowa i zaniechaniu przez niego zbrojnej interwencji w Polsce. Dla zwolenników reform Chiny długo stanowiły wzór do naśladowania.

Na początku 1958 r. doszło do zmiany polityki w całym bloku komunistycznym. W Polsce umocniła się ekipa rządząca i supremacja radziecka nad naszym krajem. Dały się zauważyć oznaki świadczące o akceptacji Kremla dla nowego przywódcy PZPR. Sam Gomułka już w 1957 r. zaczął głosić konieczność walki zarówno z dogmatyzmem, jak i z rewizjonizmem. Uznał przy tym, że walka z rewizjonizmem jest ważniejsza, porównując dogmatyzm do grypy, rewizjonizm zaś do gruźlicy ${ }^{120}$.

W 1958 r. polityka ChRL zmierzała dokładnie w odwrotnym kierunku niż w czasach kampanii stu kwiatów. Realizowano tam politykę „trzech czerwonych

${ }^{117}$ Notatka w sprawie zagadnień moralno-światopogladowych w prasie, Archiwum Akt Nowych w Warszawie, 237/XIX-119, s. 38.

118 R. Zambrowski, Dlaczego Gomutka..., s. 149.

119 W. Roszkowski, Historia Polski... s. 246.

${ }^{120}$ P. Codogni, Rok 1956..., s. 145. 
sztandarów", która wiązała się z wprowadzeniem komun ludowych na wsi i wielkiego skoku w przemyśle. Chiny miały osiągnąć niewyobrażalny wzrost produkcji poprzez wprowadzenie komunizmu o wiele bardziej radykalnego niż radziecki. Zmieniła się również polityka ZSRR, czego przejawem było potępienie Jugosławii. W Polsce zyskiwały na znaczeniu opinie o konieczności zerwania $\mathrm{z}$,nadmierną tolerancją" wobec osób i instytucji przeciwnych socjalizmowi.

Ze wspomnień Romana Zambrowskiego wynika, że problem rewizjonizmu był postrzegany jako poważne zagrożenie przez większość działaczy PZPR. Jak pisze ten autor, liberalizacja, która nastąpiła w Polsce po VIII plenum, nie tylko uwolniła reformatorskie nurty w partii, ale i umożliwiła wygłaszanie poglądów antysocjalistycznych i klerykalnych ${ }^{121}$. Podobnie oceniała to w dziennikach z 1958 r. Maria Dąbrowska, przedstawicielka laickiej lewicy: Walka Kościoła z państwem - bo wobec miażdżcej przewagi zwolenników Kościoła tak to trzeba nazwać - rozwija się i przybiera na sile. Ze zgroza myśle, co z tego dla Polski wyniknie. [...] Prawdę mówiąc, Kościót nigdy jeszcze chyba nie miat w Polsce takiego znaczenia jak dziś. Po prostu panoszy się zuchwale i zaczyna się uciekać do metod postępowania, jakie zwalczał u komunistów. Nietolerancyjność i ciemnota naszych katolików przechodzą ludzkie pojęcie $e^{122}$. Ta wypowiedź w porównaniu z poprzednimi, bardzo antystalinowskimi deklaracjami autorki może świadczyć, że niektóre zjawiska, jakie miały miejsce po 1956 r., zaniepokoiły nawet elity PRL krytycznie nastawione do stalinizmu. Wzrastające wpływy Kościoła katolickiego i lansowanie przez niego obrazu Polaka katolika były postrzegane jako zagrożenie także przez przedstawicieli środowisk reformatorskich wewnątrz partii ${ }^{123}$. Również problem stosunku państw zachodnich do polskich ziem odzyskanych mógł zrażać wielu przedstawicieli ówczesnych elit. Mając dostęp do informacji z Zachodu, wiedzieli oni, że nie tylko Niemcy, ale i inne państwa traktują te ziemie jako ,ukradzione" przez Polaków ${ }^{124}$.

Można powiedzieć, że na przełomie lat 1956-1957 radykalnie zmieniał się klimat polityczny zarówno w Polsce, jak i w całym bloku komunistycznym. O przeprowadzeniu, jak również o zaniechaniu dalszych przemian, a nawet odwrocie od reform październikowych zadecydowały więc czynniki wewnętrzne i zewnętrzne, wśród których niesłychanie istotna była także zmiana polityki ChRL.

${ }^{121}$ R. Zambrowski, Dlaczego Gomułka ..., s. 142-145.

${ }_{122}$ M. Dąbrowska, Dzienniki powojenne..., t. 3, s. 326.

${ }^{123}$ Henryk Słabek, Spór o rewizjonistów, „Dziś. Przegląd Społeczny”, październik 1996, s. 105-111 .

${ }^{124}$ Zob. np. M. Dąbrowska, Dzienniki powojenne..., t. 3, s. 209. 